\title{
In Pursuit of Constitutional Welfare Rights: One View of Rawls' Theory of Justice
}

\section{Citation}

Frank I. Michelman, In Pursuit of Constitutional Welfare Rights: One View of Rawls' Theory of Justice, 121 U. Pa. L. Rev. 962 (1973).

\section{Published Version}

http://scholarship.law.upenn.edu/penn_law_review/vol121/iss5/2/

\section{Permanent link}

http://nrs.harvard.edu/urn-3:HUL.InstRepos:12942298

\section{Terms of Use}

This article was downloaded from Harvard University's DASH repository, and is made available under the terms and conditions applicable to Other Posted Material, as set forth at http:// nrs.harvard.edu/urn-3:HUL.InstRepos:dash.current.terms-of-use\#LAA

\section{Share Your Story}

The Harvard community has made this article openly available.

Please share how this access benefits you. Submit a story.

Accessibility 


\title{
IN PURSUIT OF CONSTITUTIONAL WELFARE RIGHTS: ONE VIEW OF RAWLS' THEORY OF JUSTICE
}

\author{
Frank I. Michelman $\dagger$
}

A Theory of Justice ${ }^{1}$ is a remarkable book. It is learned and ambitious, deep (though multileveled), subtle (though lucid), rich and complex. It has been received with favor and fanfare by distinguished philosophical critics. ${ }^{2}$ Its topic can hardly be disdained by devotees of the law.

Some books are like cathedrals. Depth, subtlety, richness and complexity may retard comprehension however much they reward it ultimately. It is impossible to grasp and absorb this book's architectonic, hence its meaning, by simply reading it through no matter how studiously. Some sort of focused interrogative strategy may help one come to grips with Professor Rawls' monumental utterance. I have chosen to seek understanding through this not-so-philosophical question: How does the book bear upon the work of legal investigators concerned or curious about recognition, through legal processes, of claimed affirmative rights (let us call them "welfare rights") to education, shelter, subsistence, health care and the like, or to the money these things cost? ? $^{3}$

On the face of it, the bearing would appear to be direct and profound. An apparent main purpose of Rawls' book is to advance and clarify discourse about claims respecting distribution, transfer, and provision of social goods including material social goods-income, wealth, and what you can buy with them. Opinion abounds (Rawls evidently shares it) ${ }^{4}$ that our society is marked by evident and severe distributive injustice. Followers of the law may fairly worry about seeming disconnection between our ingrained notions of a legal order and these urgent, if debatable, ${ }^{5}$ questions of distributive justice-at least insofar as we mean by "distributive justice" an outcome-oriented

$\dagger$ Professor of Law, Harvard Unversity. B.A. 1957, Yale University; LL.B. 1960, Harvard University.

1 J. RawLS, A ThEORY OF JUSTICE (1971) [hereinafter cited as RawLs].

2 E.g., Hampshire, A New Philosophy for the Just Society, N.Y. REv. of Books, Feb. 24, 1972 .

3 I shall have in mind mostly claims against "sovereign" legislatures, or against their agents or instrumentalities.

4 RawLS 87.

5 See, e.g., Bell, On Meritocracy and Equality, 29 PUв. INTEREST 29 (1972). 
appraisal of the pattern and makeup of distributive "shares" precipitated by economic, political, and other societal processes, as distinguished from concern for the correctness of the processes themselves or the purity of their application. For it can hardly be doubted that the mainstream of our legal tradition has largely bypassed the outcome-appraising sort of distributional concern. Lawyers and jurists, like economists and political scientists, seem to have instinctively placed distributive-share questions beyond the province of their specialized analysis, "science," and technique. ${ }^{6}$ They work under a paradigm of legal order which is noticeably lacking in norms, principles, and categories of analysis directly applicable to the evaluation of distributional outcomes. The notion of justice inhabiting that paradigm has been essentially corrective and regulative, stabilizing and preservative -if not of any extant distributional configuration, then of an extant framework of procedures and practices within which distributions are secreted. Insofar as the legal system and its operatives have not abstained entirely from the distributive-share thicket, their modern forays into it have often and to many appeared fitful, unprincipled, and apologetic.?

Perhaps the legal order's failure to deal confidently with distributive share questions betrays an underlying, widely shared (if uneasy and often unacknowledged) conviction that a good distribution is unknowable except as the actual historical outcome of a good procedure -that justice consists precisely in abiding the outcome of a just procedure, and injustice in corruption of the procedure or refusal to accept its results. ${ }^{8}$ Even if some philosophers can rise above that conviction, there may conceivably be other considerations endemic in a "proper" (or optimally useful) idea of a legal order which could explain its lack of focus on issues of distributive-share justice. Most plausibly, public acceptance--presumably an essential trait of a legal order-might be felt to depend on the system's finding refuge in "neutral" procedures from evident authorship of particular outcomes."

6 See Tribe, Policy Science: Analysis or Ideology, 2 Prar. \& Pub. Aframs 66, 82 (1972).

${ }^{7}$ See, e.g., Schoettle, The Equal Protection Clause in Public Education, 71 CoLor. L. Rev. 1355, 1416-18 (1971), and opinions cited therein. See also Winter, Poverty, Economic Equality, and the Equal Protection Clause, 1972 SuP. CT. REv. 41.

$8 \mathrm{~A}$ complete theory and argument along these lines is under preparation by Professor Robert Nozick. His forthcoming Anarchy, State, and Utopia will criticize Rawls' work from just this standpoint.

9 Tribe, supra note 6 , at 82 , suggests another explanation for "proceduralism" in legal thought: that it 'has served largely as an 'economic' vehicle of concern for endresult maximization"-i.e., the procedures have been justified "in terms of their supposed tendency to maximize aggregate satisfaction in the end." This interpretation converges with the one in the text in its suggestion of unconcern with distributive shares as distinguished from production totals. 
Yet neither explanation of the legal order's preoccupation with procedural justice is fully satisfactory if it can be shown that some outcomeevaluative principles are accepted more or less consensually in society, even if only intuitively and abstractly. If there are such latent consensual notions of justice in distributive shares, if these are ostensibly dishonored by society's economic and political institutions, and if these failures are in turn ignored by the legal organs, then there might be cause for concern about continued public acceptance of the total system-though not necessarily reason to conclude that it is the legal organs that have failed, or through which the way to salvation now lies.

Now Rawls presents an argument calculated to persuade us that such outcome-oriented notions of distributive-share justice do indeed exist. He tries to show how "our" introspectively detected "moral capacity" or "sense of justice"-meaning the whole set of our day-today moral judgments together with the supporting reasons we would tend to give (our "considered judgements") - can be parsimoniously captured in a few abstract statements (the "principles of justice").10 These principles are connected up with a few other weak and broadly acceptable posits (those governing the "original position") ${ }^{11}$ by a striking and appealing (contractarian) form of argument, designed to show that they are the principles which would be unanimously adopted by persons of whose traits and situation those posits were true. ${ }^{12}$ The

10 The definitive statement of the principles may be found in note 23 infra.

11 Persons in the original position are assumed to be (a) mutually disinterested, being neither envious of nor dependent upon one another's well-being, RawLs 143, 281, 538, and (b) rational, meaning that their happiness is determined by success in carrying out a long-term plan of life "designed to permit the harmonious satisfaction of ... interests" by "schedul[ing] activities so that various desires can be fulfilled without interference." Id. 93. Such persons prefer for themselves more rather than less of the social "primary goods"-"rights and liberties, opportunities and powers, income and wealth," and "a sense of one's own worth"-required for carrying out such plans. Id. 92. They are formal and moral equals with regard to their claims to participate and have their views counted, $i d$. 19, a condition made operative in the original position by a requirement of unanimous agreement on the principles of justice, id. 141-42. And they are equals with respect to their claims to happiness or success in carrying out their plans, a condition made operative by the supposition that they deliberate under a "veil of ignorance" as to their actual, particular circumstances, and by the associated requirements that any principles of justice selected be general and universal. Id. 131-33.

12 The following paragraph seems to capture much of the essence of the contractarian approach:

[F] or one who understands and accepts the contract doctrine, the sentiment of justice is not a different desire from that to act on principles that rational individuals would consent to in an initial situation which gives everyone equal representation as a moral person. Nor is it different from wanting to act in accordance with principles that express men's nature as free and equal rational beings. The principles of justice answer to these descriptions and this fact allows us to give an acceptable interpretation to the sense of justice. In the light of the theory of justice we understand how the moral sentiments can be regulative in our life and have the role attributed to them by the formal conditions on moral principles. Being governed by these principles means that we 
whole scheme-abstractly stated principles embedded in their contractarian derivation-composes a "moral theory" which is supposed to impart a sense of system to the day-to-day, intuitive considered judgments we already have. Rawls evidently expects that "our" considered judgments will turn out to be on the whole, but not uniformly, consistent with the philosophically elaborated moral theory. Thus the moral theory-insofar as successful-can serve to clarify our understanding of, and strengthen our commitment to, our day-to-day considered judgments and can also serve, through its own coherence and general consistency with our more casual sense of justice, to alter those day-to-day judgments at least'marginally. We can test the theory by the closeness of its fit to our judgments, after those have undergone adjustment in light of exposure to the theory-what Rawls calls our judgments in "reflective equilibrium."13

The theory is thus expressly aimed at bringing out and systematizing moral notions which are supposed to be already implanted in the bulk of the book's readership. Moreover, the suggested principles of justice, while relying in part on elements of "pure procedural justice," do ultimately demand, in addition, appraisal of outcomes. ${ }^{14}$ And these principles, and the arguments supporting them, appear to proceed from the broad tradition of "western" individualistic democratic liberalism

want to live with others on terms that everyone would recognize as fair from a perspective that all would accept as reasonable. The ideal of persons cooperating on this basis exercises a natural attraction upon our affections.

Id. 478 .

13 For discussion of the mutual adjustment of principles and considered judgments, and the resultant state of reflective equilibrium, see id. 19-22, 46-52, 579.

14 See, e.g., id. 507-08. "[P] ure procedural justice," says Rawls, "obtains when there is no independent criterion for the right result: instead there is a correct or fair procedure such that the outcome is likewise correct or fair, whatever it is, provided that the procedure has been properly followed." $7 d .86$.

The interaction in Rawls' theory between a "pure procedural" orientation and an "outcome" or "substantive justice" orientation is complex and quite fascinating. The original position can itself be regarded as a procedure so constructed that whatever principles emerge will be ipso facto "just"-the idea, as Rawls says, being "to use the notion of pure procedural justice as a basis of theory." Id. 136. Yet the procedure is deliberately constructed so that it will yield principles generally conforming to whatever substantive notions we start with, id. 19-20-such as those of moral and formal equality, mentioned in note 11 silpra. Of course, the rabbit that goes in the hat is, however transformed by contractarian magic, the rabbit that comes out; and just as the original position is a procedure both cherished for its own procedural sake and constrained by substantive notions of freedom and equality, so is the social system implied by the resulting principles of justice:

The intuitive idea is familiar. Suppose that law and government act effectively

to keep markets competitive, resources fully employed, property and wealth ...

widely distributed ..., and to guarantee a reasonable social minimum. Assume also that there is fair equality of opportunity underwritten by education for all; and that the other equal liberties are secured. Then it would appear that the resulting distribution ... will tend to satisfy the difference principle [paragraph (a) of the Second Principle of Justice, note 23 infra]. In this complex of institutions, which we think of as establishing social justice in the modern state, the RawLS 87 .

advantages of the better situated improve the conditions of the least favored. 
within which our characteristic notions of legal order and doctrine have arisen. ${ }^{15}$

One can thus well imagine that constitutional lawyers and scholars, seeking or weighing legal definition, recognition, and enforcement of welfare rights, would eagerly take to Rawls in search of a principled account of such rights-one which could be used to support or explain such legal events (actual or desired) as inclusion of specific welfare guaranties in a constitution ${ }^{16}$ or determinations by the judiciary that some such guaranties are already present in the spacious locutions of, say, section one of the fourteenth amendment. ${ }^{17}$

By a "specific welfare guaranty" (or, as I shall sometimes say, an "insurance right") I mean a right to provision for a certain need -on the order of shelter, education, medical care-as and when it accrues. I put the matter this way even though, as will appear, it is easier and more natural to find in Rawls support for more generally formulated rights to guaranteed money income at some fixed or calculable rate (e.g., not less than half the median income), or-more generally still-for rights against excessive or unnecessary inequality of wealth or income. But as long as one is asking what Rawls has to contribute to the promotion of welfare rights that are justiciablethat is, susceptible of convincing recognition and enforcement by officers acting subject to the restraints of judicial office-the special focus on insurance rights seems at least provisionally in order. However strange may seem the nomination of welfare insurance rights as early candidates for direct judicial recognition as components of, say, due process or equal protection, most of us will feel intuitively that constitutional minimum-income rights are less likely still. ${ }^{18} \mathrm{~A}$ like tactical preference for insurance rights may seem less clear-cut when

15 The names of Aristotle, Kant, J.S. Mill, and Sidgwick are especially prominent. For a discussion of Rawls' affirmance of this liberal tradition, see McBride, Social Theory Sub Specie Aeternitatis: A New Perspective, 81 YaLE L.J. 980, 987-90, 993-95 (1972).

26 An example of a proposed inclusion of welfare guaranties in a state constitution appears in Morris, New Horizons For a State Bill of Rights, 45 WASE. L. REv. 474, 490 (1970):

Art. XXVII. State Responsibility To Protect Social And Economic Rights. The

State of Washington through its legislature and other divisions of government shall foster the health and welfare of its citizens, through a partnership of public agencies and voluntary organizations wherever practicable, by providing: care for the helpless, the needy, and the sick; protection against physical and mental illness; conditions encouraging maximum realization of the individual's independence; freedom from discrimination, unemployment, and the anxieties of old age; personal safety; and decent housing, recreation facilities and aesthetic surroundings.

17 See, e.g., Michelman, Foreword: On Protecting the Poor Through the Fourteenth Amendment, 83 Harv. L. REv. 7, 14-16 (1969). The cited article should be compared with the vigorous criticism of it found in Winter, supra note 7.

18 See Michelman, supra note 17, at 14. 
constitutional amendment is the chosen avenue of reform (and a minimum-income guaranty, once ensconced in a constitution, need by no means be less justiciable than a guaranty of, say, "decent shelter"); but I believe there are reasons why insurance rights might be more attractive than minimum income rights to devotees of constitutional amendment. These reasons will emerge from subsequent discussion. ${ }^{19}$

None of the above is to assert finally that justiciable welfare rights are a good thing, and certainly not to deny that "rights" may be recognized and made influential in societal affairs otherwise than through adjudication. It is simply that the task I have chosen is to see what can be learned of Rawls by searching in his book for justiciable welfare rights. Like any other heuristic device, this one will have to be judged by its results. And, of course, it is just possible that the experience of the search will teach us something about whether justiciable welfare rights ought to be pursued at all.

\section{$* * *$}

Numerous questions, arising in various perspectives and at various levels, stand between us and a final appraisal of what, if anything, Rawls' theory has to contribute to a legal conception of justiciable welfare rights. It may help at this point to chart these questions in their broadest outlines.

To begin with, we have to note that Rawls is mainly concerned with what he calls "ideal theory"-the selection, defense, and working out of principles of justice for and in the supposed context of a society which is "well-ordered" or in a state of "near justice." The crucial assumption of ideal theory is that the principles of justice (whatever ones are under examination) are generally and explicitly acknowledged, accepted, and on the whole applied in the society. It is on that assumption that the implications and consequences of the principles are worked out and appraised.

This feature of Rawls' work immediately suggests a major division for our exploration. We should first try to discover whether and to what extent the ideal theory itself (that is, the theory as worked out for a society supposed to be well-ordered by the very criteria it implies) suggests welfare rights that are judicially enforceable. But we must then consider whether our society is well-ordered (or potentially well-ordered) in the indicated sense, and if not, what then follows. For a theory which suggests justiciable welfare rights for a society which is well-ordered might lead to different conclusions for one which is not. Conversely, and perhaps more important, it may 
turn out that even if the theory does not indicate justiciable welfare rights under ideal conditions, it suggests them as a way of coping with nonideal conditions.

Focusing, then, on ideal theory, we encounter a second major division of inquiry. We want to know, of course, whether the principles of justice have a substantive content which points to welfare rights and, if so, what specific shape these rights might take; but we need to ask also whether the theory contemplates that any such rights would be set forth in a written constitution and (a different though related question) whether they would be enforceable in the face of legislative failure by judicial review. The same duality of "substance" and "procedure" will help organize our pursuit of the theory into its nonideal applications.

Lurking behind all this is still another major inquiry. Even if we decide that Rawls' theory suggests, for our society (well-ordered or not as the case may be), the constitutionalization and judicial enforcement of welfare rights, we shall have to consider what claims this theory might have to govern or influence the decisions of our judges. This last question-whether, how, or why Professor Rawls' Theory of Justice, any more or less than Mr. Herbert Spencer's Social Statics, ${ }^{20}$ is to become an operative force in constitutional adjudication-will be explored in the last part of this essay.

\section{IDEAL THEORY}

\section{A. Substantive Content}

\section{The Notion of the Basic Structure}

One must consider first the level of generality at which Rawls formulates his theory of justice as fairness. That theory proposes to address only

the basic structure of society, or more exactly, the way in which the major social institutions distribute fundamental rights and duties and determine the division of advantages from social cooperation ... . The intuitive notion here is that this structure contains various social positions and that men born into different positions have different expectations of life determined, in part, by the political system as well as by economic and social circumstances. . . . It is these inequalities ... to which the principles of justice must in the first instance apply. These principles, then, regulate the choice of a politi-

20 See Lochner v. New York, 198 U.S. 45, 74, 75 (1905) (Holmes, J., dissenting). 
cal constitution and the main elements of the economic and social system. ${ }^{21}$

The notion of the basic structure may be crucial to the welfare-rights search, for it contains what may be the most persuasive line of response to the most compelling line of objection to welfare rights, that such rights signify redistribution from the prudent and industrious to those who have culpably failed to grasp opportunities to provide for their own security. The notion of the basic structure suggests the possibility that society now contains a correctible shortage of economically secure positions (or an excess of insecure ones); and welfare rights can then be appraised as a possible corrective device.

At the same time, the focus of justice as fairness on the basic structure may pose difficulties for the welfare-rights search. This focus means that the theory's principles of justice are selected for their capacity to serve as rather abstract, broad-gauged constraints against which to test more specific and circumstantially contingent proposals at the constitutional and legislative levels. And insofar as the recognition and specific content of welfare rights may, within these constraints, vary according to societal circumstances and how other available choices (regarding the basic structure) are made, a justiciable catalogue of welfare rights cannot directly appear. One might, though, be rather strongly and clearly implied once the relevant circumstances and other choices for our particular society are revealed and plugged in. This is the possibility we must pursue.

\section{Managing the Tension Between Liberty and Equality}

It is no longer possible to avoid an attempt, however lame, to expound in some way the substance of the theory we are to explore. I shall do this by examining a question which is peripherally relevant to my main inquiry here, and of some general interest: the way the theory manages the familiar tension between liberty and equality. Now creditable handling of this issue involves either resolution of the tension or, admitting that the tension cannot be resolved, refinement (or clarification) of our understanding of the problem. A resolving theory would show that there is no true conflict, that the ends connoted by "liberty" and "equality" are perfectly reconcilable with each other and fully achievable within the same social order; or else it would resolve such irreconcilable conflict as must be admitted by ranking the ends hierarchically, not permitting subordinate ones to impede 
full achievement of superior ones. A refining theory, on the other hand, would frankly accept a relationship marked by continuing equilibration, shifting readjustment, at most an endlessly dialectical sort of "progress" towards ultimate settlement. A refining theory may positively value such a tense relationship as a source of social dynamism and resilience, but it need not. ${ }^{22}$

As a starting point of our examination of Rawls' handling of the liberty-versus-equality issue, let us examine his principles of justice, arrayed in the "lexical" order he prescribes: ${ }^{23}$

\section{First principle: Maximum equal civil and political ("ba- sic") rights and liberties.}

22 With regard to the question of distributive shares, one sort of resolving theory would be an anarchistic one which simply forbids interference with maximum mutual liberties of acquisition and trade for redistributive purposes. A contrasting type would be a communistic one which demands as much interference with such liberty as is necessary to achieve perfect equality of after-tax incomes. Utilitarianism, as usually understood, belongs in the refining category. Utilitarianism is, to be sure, characterized by a "teleological" structure in which "the good is defined independently from the right," and then the right is defined as that which maximizes the good, id. 24. But the good to be maximized in utilitarianism is not usually identified as either liberty or equality; both are treated as subordinate items to be optimally mixed, subject to contingencies, in the overriding interest of some other, perhaps hedonistic, "greatest good." Most obviously excluded from the resolving class are "intuitionist" theories-those which hold "that there is an irreducible family of first principles [such as liberty and equality] which have to be weighed against one another by asking ourselves which balance, in our considered judgment, is the most just," and that "there exist no higher-order constructive criteria for determining" the proper balance. Id. 34 .

23 The "lexical" or "serial" ordering "means that a departure from the institutions of equal liberty required by the first principle cannot be justified .... or compensated for, by greater social and economic advantages. The distribution of wealth and income, and the hierarchies of authority, must be consistent with both the liberties of equal citizenship and equality of opportunity." Id. 61. The full, definitive statement of the principles is as follows:

First Principle

Each person is to have an equal right to the most extensive total system of equal basic liberties compatible with a similar system of liberty for all.

Second Principle

Social and economic inequalities are to be arranged so that they are both:

(a) to the greatest benefit of the least advantaged, .... and

(b) attached to offices and positions open to all under conditions of fair equality of opportunity.

First Priority Rule (The Priority of Liberty)

The principles of justice are to be ranked in lexical order and therefore liberty can be restricted only for the sake of liberty. There are two cases:

(a) a less extensive liberty must strengthen the total system of liberty shared by all;

(b) a less than equal liberty must be acceptable to those with the lesser liberty.

Second Priority Rule (The Priority of Justice over Efficiency and Welfare) The second principle of justice is lexically prior to the principle of efficiency and to that of maximizing the sum of advantages; and fair opportunity is prior to the difference principle. . .

(a) an inequality of opportunity must enhance the opportunities of those with the lesser opportunity....

Id. 302-03. 
Second principle:
A. Fair equality of opportunity;
B. Only such social and economic inequali- ties as work for the benefit of the worst- off position (the "difference principle").

Working backward from observed social and economic inequalities, the total effect can be stated this way: such inequalities are permissible (indeed, desired) if, but only if (1) the arrangements generating them work out better for the worst-off position defined by those arrangements than would any more equal structure (the "difference principle"); (2) the various positions defined by the arrangements are formally open to all and "fair equality of opportunity" (particularly including some amount of compensatory education) is provided (the "opportunity principle"24); and (3) in any event the civil and political "basic" rights and liberties of citizens are equal and as extensive as possible consistent with this condition of mutuality (the "liberty principle").

Although Rawls' emphasis on the ordering of the two principles might suggest he is arguing for some kind of resolution under which liberty dominates equality, and although, conversely, some critics seem to read him as a "resolver" for whom equality dominates liberty" (and some passages in the book do suggest such a reading ${ }^{26}$ ), the truth appears to be that Rawls offers refinement, not resolution, of the liberty-equality tension. His difference principle ${ }^{27}$ is, to be sure, not intuitionist, ${ }^{28}$ for it asserts a unitary constructive criterion for appraising distributive outcomes; and it is not utilitarian, for that unitary criterion cares not for maximization across an entire social order of some universal good. But the difference principle, I believe, has in common with both intuitionist and utilitarian theories an acceptance of a tense dynamic relationship between liberty and equality which 41.

24 "Opportunity principle" is my tag-line, not Rawls".

25 E.g., Bell, supra note 5; Kristol, About Equality, CommentaRy, Nov. 1972, at

20 For example, Rawls says: "The naturally advantaged are not to gain merely because they are more gifted, but only to cover the costs of training and education and for using their endowments in ways that help the less fortunate as well." RAwLs 101-02 A similar statement is found at $i d$. 158. If Rawls means that the "naturally advantaged" are not to receive any extra income except what would cover training costs and "hazard pay," he would indeed be a radical equalizer. But taking the book as a whole and all passages in context, it seems to me that Rawls means to justify a much broader notion of incentive and that he is prepared to accept quite substantial inequalities as a result. He is explicit as to the latter point, $i d .158$.

27 Paragraph (a) of The Second Principle, note 23 supra.

28 For Rawls' definition of intuitionism, see note 22 supra. 
is highly sensitive to contingent circumstances. ${ }^{29}$ This interpretation, if correct, can certainly be expected to bear upon the difference principle's capacity to generate justiciable welfare rights. ${ }^{30}$

In suggesting that the difference principle accepts a continuing relationship of tension between liberty and equality, I have in mind especially that part of liberty associated with rights of propertywith getting, keeping, and disposing over the use and enjoyment of things of value. This aspect of liberty is perhaps most obviously in potential conflict with equality. A crucial question, then, is: do the lexically preferred civil and political ("basic") liberties include those of acquiring, keeping, enjoying, and transmitting property? Perhaps surprisingly, Rawls never seems to answer this question explicitly. ${ }^{31}$ But perhaps it is enough for us to see that an unqualified lexical preference for súch acquisitive and retentive liberties would imply an anarchistic resolution totally subverting the opportunity and difference principles by forbidding the taxation needed to carry them outwhich cannot be what Rawls means. ${ }^{32}$

29 When Rawls states that "the two-part basic structure [i.e., the bifurcated statement of the two principles and the First Priority Rule, note 23 supra] allows a reconciliation of liberty and equality," Rawis 204, he seems to be addressing himself to a different, and less baffling, question: how citizens can be "equal before the law" (as we might say) even as the law allows substantial inequalities of position, power, income and wealth.

30 See text accompanying notes 43-72 infra. It should be noted at this point that the difference principle offers a test and not a prescription. With respect to it, Rawls says: "Often the best that we can say of a law or policy is that it is at least not clearly unjust." Rawls 199.

31 Rawls defines the basic liberties as follows:

The basic liberties of citizens are, roughly speaking, political liberty (the right to vote and to be eligible for public office) together with freedom of speech and assembly; liberty of conscience and freedom of thought; freedom of the person along with the right to hold (personal) property; and freedom from arbitrary arrest and seizure as defined by the concept of the rule of law.

RAwLS 61. The qualifier "(personal)" is, in context, evidently meant to exclude at least the means of production and so recognize that socialist schemes may be just. The "right to hold" admits easily of regulation and taxation insofar as they are designed "to prevent concentrations of power detrimental to the fair value [i.e., effective equality] of political liberty," id. 277, since the lexically preferred first principle calls for "an equal right to the most extensive total system of equal basic liberties compatible with a similar system of liberty for all," $i d .302$ (emphasis added), so that some basic liberties may be restricted for the sake of others, id. 203-04. But taxation to satisfy the opportunity and difference principles (which Rawls explicitly contemplates, id. 277-79) would seemingly violate the First Priority Rule, note 23 supra, unless "(personal) property" (as included among the lexically preferred "basic liberties") means only those possessions required for individual human functioning.

32 If, on the other hand, the opportunity and difference principles are to be saved from such extinction by reading basic liberties as not to encompass property claims, we must be sure that no trouble of a different sort ensues when we try to grasp the true operative significance of the proposed lexical ordering. It seems that in contexts which come readily to mind, the ordering's force will be exhausted by ranking both the liberty and opportunity principles as superior to the difference principle, saying that both liberty and opportunity must be assured before any residual inequalities, even those satisfying the difference principle, are permitted. It clearly means something to say that the liberty principle is lexically prior to the difference principle, even if property rights are not a part of liberty. For it might happen that rather extreme social and economic 
Let us now introduce some terms not used by Rawls and incorporate them in a more complete statement of the second principle. Let us use "occupational liberty" to mean freedom in choice of productive activity, and "dispositive liberty" to mean freedom to dispose over the proceeds (these two liberties together comprising a notion of "proprietary" liberty or "property rights"). Then the "two" principles of justice might read as follows (with all principles and subprinciples ranked in the order given):

First principle:

A. Liberty principle (maximum equal civil, political, and occupational liberties).

Second principle:
B. Opportunity principle.
C. Difference principle.
D. Disposition principle (dispositive liber- ties to be respected).

This statement would make clear that when the opportunity or difference principles collide (as they must) with the dispositive aspect of proprietary liberty, it is the latter which must give way. At the same time, by revealing proprietary liberty (including the disposition aspect) as itself a principle of justice, the statement makes clear that the opportunity and difference principles are not unrestrained counsels of levellism.

\footnotetext{
inequalities would lead to greater income for the worst-off than a more equal arrangement, but that such an extreme degree of inequality would undermine effective equality of political and civil rights; and in that case the lexical priority of liberty would mean that the more equal arrangement is required even at some sacrifice in income for the worst-off. See note 31 supra. Likewise, the lexical priority of the opportunity principle over the difference principle has plausible applications. Certain extremes of social and economic inequalities might promise more income for the worst-off but only at the cost (or possibly by the very means) of establishing a hereditary aristocracy or other classbound social structure. Such inequalities would be forbidden. See RawLs 74, 278, 300-01. It is harder to find operative significance in the statement that the liberty principle is lexically prior to the opportunity principle, because (still assuming that property claims are not a part of the preferred "liberties") it is harder to see how these can ever come into conflict. What application can be found for the proviso in the statement that positions are to be formally open to all under conditions of fair equality of opportunity-provided that maximum mutual civil and political liberty is assured to all citizens? There is, at least, the case in which someone's exercise of free speech rights is thought to interfere with fair equality of opportunity-e.g., by expounding a scientific theory of racial inferiority. Here the lexical ordering would apparently forbid any curbs on speech. Another case which comes to mind is a proposal to bring about equality of opportunity by holding back the naturally gifted. Such a tactic would plainly be disapproved by Rawls, but the disapproval is to be found in the definition of the concept of fair equality of opportunity, not in the priority rules. See text accompanying note 73 infra. Still, this case suggests a possible exegetical canon which we should keep in mind: that the priority rules, and the idea of lexical orderings, are not to be understood in a crudely fundamentalist or vindictively literal way, but rather to be taken more loosely as a way of lending shape and structure to the entire doctrine, which is to remain supple and not hidebound.
} 
Suppose we have arrived at a set of arrangements affording fair equality of opportunity and satisfying the difference principle in the minimal sense that no reduction in inequality will improve the lot of the disadvantaged. In this region the fine tuning seems most naturally to take the form of taxation of the best- (or better-) off representative person ("the top") in order to transfer the proceeds to the worst(or worse-) off representative person ("the bottom"). To say that the difference principle is minimally satisfied means that the top has already been pared down, and the bottom already lifted, by such taxes and transfers to the point where the disincentive effect of a further increment of taxation will reduce GNP by just enough to offset the bottom's increased relative share, so that the bottom's absolute situation will remain unchanged. Now suppose that there is some appreciable range over which addititional taxation could further pare down the top without lowering the bottom or raising it, but making the distribution more equal. ${ }^{33}$ The suggested insertion of a "disposition principle" into the hierarchy of principles of justice means that in this case Rawls would prefer the less equal distribution-that is, the one which, ceteris paribus, maximizes dispositive liberty. Various considerations can be marshalled to show that this is indeed what Rawls means.

With regard to distribution of shares, respect for dispositive liberty is equivalent to adherence to the criterion of efficiency or Pareto-optimality. ${ }^{34}$ Both would protect the top from transfers designed to reduce inequality, without raising the bottom's absolute level. Rawls is explicit that efficiency is a proper criterion of choice between distributions which are in all other relevant respects similar; ${ }^{35}$

33 The discussion at this point ignores the possible interactions between the bottom's relative situation and its absolute situation: that is, it disregards the possibility that further paring down of the top will bring net improvement to the bottom's situation, even while it fails to raise the bottom's real money income, because it alleviates "relative deprivation" effects. It seems justifiable to consider cases in which no such phenomenon occurs, wholly apart from any possible doubts about the reality of relative deprivation. These cases may arise either because within the range of additional transfers we have in mind-those which will not lower the bottom's real money income-no noticeable alleviation of relative deprivation will occur (i.e., there are discontinuities in the function relating the intensity of tax-transfer activity to the magnitude of relativedeprivation effects); or because, assuming no such discontinuities, there is a range of tax-transfer increments within which reduction of the bottom's real money income will be just offset by reduction of relative deprivation. The problem of 'relative deprivation is further considered at note 57 infra \& accompanying text, and at text accompanying notes $68-70$ infra.

34 [A] configuration is efficient whenever it is impossible to change it so as to make some persons (at least one) better off without at the same time making other persons (at least one) worse off. Thus a distribution .... among certain individuals is efficient if there exists no redistribution ... that improves the circumstances of at least one of these individuals without another being disadvantaged.

RAwLS 67.

35 See id. 66-72. 
and Rawls' argument and statement of the principles, taken altogether, indicate rather strongly that increments of inequality do not, in and of themselves, constitute relevant counter-arguments. ${ }^{36}$

This reading is indirectly bolstered by its consistency with a number of factors in the total argument, including: (1) the intuitive argument for choosing the difference principle in the original position, which relies on probabilistic appraisal of alternatives, conditioned by special sensitivity to downside risk; ${ }^{37}$ (2) the emphasis given the contention that envy should be disregarded in constructing this choice; ${ }^{38}$ (3) the strong intimations that there is positive moral value in allowing distribution to be as much as possible a matter of "pure procedural justice, ${ }^{\prime 39}$ together with (4) the clearly expressed preference for occupational liberty; ${ }^{40}$ and (5) the textual irresolution, noted above, concerning the inclusion of property rights in the lexically preferred basic liberties. ${ }^{41}$

In sum, the Rawlsian ethic calls for inequalities to be reduced to a point, but also to be allowed (even favored) to a point. The subprinciples of the second principle of justice, taken all together, can only be called a set of precepts for adjusting tension between equality and proprietary liberty-tension which is not about to disappear. At this particular value-frontier, there is no effective lexical ordering. The precepts of the second principle, while they may well strike us as a compelling way of accommodating proprietary liberty with an adequate notion of human moral equality, do all the same compose a mode of accommodation, not of resolution. ${ }^{42}$ We should not be surprised, then,

36 See note 23 supra. Note especially paragraph (a) of the Second Principle and the first clause of the Second Priority Rule.

The following statement of the difference principle suggests that Rawls would favor additional taxation which would lower the top without raising the bottom: "[T]he higher expectations of those better situated are just if and only if they work as part of a scheme which improves the expectations of the least advantaged members of society." RAwIS 75 (emphasis added). But that statement should be compared with the following definition of Rawls' principle of efficiency, which suggests that Rawls would oppose such transfers:

[A]n arrangement of rights and duties ... is efficient if and only if it is impossible ... to redefine the scheme of rights and duties, so as to raise the expectations of any representative man ... without at the same time lowering the expectations of some... other representative man.

Id. 70 (emphasis added).

37 Compare id. 152-54 with id. 164-66.

38 Id. $143-44,538$.

30 Id. 83-88, 274-75.

40 Id. $272-73,276$.

41 Text accompanying note 31 supra.

42 The Second Principle expresses a rather sophisticated notion of the moral equality of mankind. See Raws 504-12. Accidents of birth and natural endowment being, in this view, morally irrelevant, social institutions are to be designed so as to allow nature's endowments of ability to work for the good of all, not just for the good of the gifted. Id. 100-04; see also id. 74-75. One might be tempted to say that the opportunity and 
if these precepts are indeterminate and debatable in their contingent applications.

\section{Welfare Implications of Justice as Fairness}

We turn now to a more specific search for the welfare-rights implications of the principles of justice. It will be convenient to consider separately the difference principle, the opportunity principle, and the liberty principle in that order. Eventually we shall have to consider the meaning and bearing of the theory as a whole.

\section{a. The Difference Principle}

Within the general framework of a free-market system, the difference principle is said to imply a claim on behalf of each person to a "social minimum" which must be provided in order that the residual market determination of distributive shares may be considered just. Although this claim could perhaps be satisfied, partly if not wholly, by legislative creation of insurance rights concerning minimum levels of service to such needs as subsistence, health, and the like, it seems at least equally satisfiable by general monetary transfer schemes such as negative income taxes. ${ }^{43}$ Even if the latter method is preferred, it seems worth considering whether the dollar value of the minimum (most likely expressed as a rate of income) might be shown to depend on, or reflect, which particular needs are to be covered and at what levels. If so, it may be possible to construct constitutional insurance rights out of the "social minimum" conception. If not, the difference principle's welfare-rights implications will be exhausted by a minimumincome claim which, I have suggested, ${ }^{44}$ will tend to be less justiciable than a set of insurance rights.

Our study of the difference principle's insurance-rights implications will proceed in the following way. We shall first pursue the matter on the assumption that the bottom's prospects (which the difference principle requires to be maximized) are to be defined in terms only

difference principles, serially coupled, are indeed a kind of definition of what Rawls means by the statement that persons are "equal." These coupled principles might be seen as the operationalized expression of his moral notion of equality as applicable to social institutions. This interpretation gains support from Rawls' willingness to entertain the idea that a suitably restricted version of the difference principle might justify inequalities in the political structure. See text accompanying notes 110-17 infra. Yet he flatly rejects the application of the difference and opportunity principles to the distribution of the most basic liberties of all, those of conscience. As to these, he calls for absolute mutuality and will not be content with institutions which would claim to have confirmed moral equality in principle by in practice maintaining unequal liberties supposed to maximize the liberties of the less free. RAwLs 206-09.

43 See Rawts 275. Rawls' notion of "primary goods" and his related strictures regarding paternalism suggest reasons why monetary transfers might be preferred. See note 11 supra; note 142 infra.

44 Text accompanying notes 17-18 supra. 
of the primary social goods of income and wealth (rights and liberties evidently being taken care of by the liberty principle). On this assumption we shall compare the difference principle with that of average utility (which Rawls plainly regards as the difference principle's most plausible competitor ${ }^{45}$ ) to see which is more receptive to a notion of welfare insurance rights. We shall then ask whether, under the difference principle, the bottom's expectations are to be maximized also with regard to the primary social good of self-respect or "a sense of one's own worth" (the most important primary good of all, as Rawls ultimately says); and if so, what difference this makes.

If we were working up a taxonomy of distributive-share precepts, one of the classifying traits we might well use would be the representative standpoint from which the distribution is regarded. For the difference principle, this is the worst-off representative person, what we have been calling the bottom. For the principle of average utility it would be the middle, or, assuming constant population, the whole. ${ }^{46}$ Another, and intersecting, distinction for distributive-share precepts might be that between precepts which are maximizing and those which are "satisficing":"7 Does the precept take the view that "more is better," or rather that "enough is enough"? This may seem a potentially fruitful distinction for our inquiry insofar as a highly articulated (that is, justiciable) conception of insurance rights may seem to fit more naturally under a satisficing than a maximizing precept. Now a precept such as average utility, which views things from the standpoint of the middle or the whole must in strict logic be a maximizing one, while a precept which views things from the standpoint of the bottom may seem more likely to be satisficing. ${ }^{48}$ It might, therefore, seem as though the difference principle would be more likely than average utility to point the way to an insurance-rights package. But of course the difference principle is itself maximizing, not satisficing; speaking for the bottom, it says that more is better. ${ }^{49}$ And the curious truth turns out

45 See Rawts 161-66.

46 Rawls' definition of average utility is more refined but leads to the same thing:

To apply this conception to the basic structure, institutions are set up so as to maximize the percentage weighted sum of the expectations of representative individuals. To compute this sum we multiply expectations by the fraction of Id. 162. society at the corresponding position.

47 See H. Smuon, Moders of MaN: Sociad and Rationad 261, 270-71 (1957).

48 If the precept is concerned only with satisfaction of minimum standards or requirements, and indifferent to variations above the minimum, it has adopted the bottom's standpoint. (If it is the precept of absolute equality, under which the minimum is also the maximum, the distinction between the two standpoints simply becomes irrelevant.)

49 This is clearly correct for the difference principle in isolation. That it is not, however, a correct statement when applied to justice as fairness, as a whole set of principles regarded from the original position, will become important later on. See text accompanying notes 77-80 infra. 
to be that average utility is the more amenable of the two precepts to constructing an argument for social insurance focused on particular needs, because it is not tied to a short list of general social goods such as income and wealth and, accordingly, allows for much more latitude and specificity in making assumptions about what people really want and need. And yet, as we shall see, the very considerations underlying this conclusion also show that the average-utility argument for insurance-rights is not an argument for "rights" at all in the sense that concerns us, but merely an argument for social expediency; and it is precisely for the reason that average utility is concerned with expediency rather than rights that Rawls rejects it as a guiding principle.

The difference principle asks whether the tax-transfer structure, with its associated incentive structure, can be altered so as to improve the situation of the bottom. ${ }^{50}$ The average-utility principle asks whether any possible alteration can increase total consumer satisfaction (assuming no change in population) ${ }^{51}$ For average utility, at least, a notion of "basic needs" might be relevant insofar as we make certain assumptions about the relationships between the intensity of a person's desire for additional quanta of certain goods and the "amounts" of those goods he already has. These assumptions, indeed, are but variations and refinements of the asumption of "declining marginal utility of income" which utilitarians commonly make in arguing for some degree of income-equalizing tax-transfer activity. ${ }^{52}$ They posit that persons now enjoying little or none of certain goods would be willing to pay, for certain increments to their existing low levels of enjoyment, amounts exceeding production costs by more than the normal market rate of profit. ${ }^{53}$ Borrowing from economic jargon, we might call this

50 See text accompanying note 33 supra. Treating tax-transfer arrangements as the only component to be manipulated may be an oversimplification, since even if these arrangements are optimal for the bottom, given the rest of the basic structure as it stands, some possible alteration of other sectors of the basic structure, or some general revision of the structure itself might improve the bottom's situation. I am simply assuming, subject to further investigation, that if even the oversimplified inquiry made here fails to yield justiciable welfare rights, they would not be derivable by a more complex inquiry, entailing still further debatable choices.

51 See note 46 supra.

52 For an elaboration and criticism of the notion of declining marginal utility of income, see W. Blum \& H. Kalven, The Uneasy Case for Progresstve Taxation 56-63 (1953).

53 Let $a, b, c$ and $d$ stand for progressively higher levels of enjoyment of some good. If $a$ is a very low level, $b$ is barely adequate, and $c$ rather high, the value of $b$ minus $a$ may greatly exceed that of $d$ minus $c$, even though there are plausible scales (e.g., production costs or physical quantities) under which the two differences are the same. Indeed, there may be no increment to $a$ which has the same value as any increment to $c$. Increments to $a$ which are smaller than $b$ minus $a$ may all be virtually worthless, and increments to $a$ at least equal to $b$ minus $a$, of great value; whereas increments to $c$ seem always to have some marginal value but never as much as $b$ minus $a$. Consider all this in the case of food (allowing increments to reflect improvements not only of quantity but of mix, variety, quality, refinement of preparation, rarity, delicacy, etc.). 
excess a "consumer's surplus" arising under nondiscriminatory pricing when dollars are spent to satisfy urgent needs arising out of deprivations, absolute or relative, not widely experienced in the economy. ${ }^{54}$

Income transfers from the top to the bottom which enable the bottom to cover the costs of such high-surplus increments would, even allowing for disincentive effects which reduce total material output, seem likely to raise the total of consumer satisfaction; and if so, such transfers would be required by average utility. ${ }^{55}$ One can imagine trying to specify for any given economy a critical list of minimum service levels regarding certain needs, such that the anti-productive effects of intensified tax-transfer activity required to enable the bottom to cover the costs of this basic set would be just offset by the welfare gained through shifting resources to the satisfaction of these hitherto unmet basic needs. This would be the point where total consumer satisfaction is at its maximum and average utility is content. Through this line of thought it is at least conceivable that under average-utility reasoning a social minimum could be exhaustively defined or calculated by reference to the costs of satisfying a basic set of minimum levels of service to particular needs. ${ }^{\text {to }}$

Of course this will seem an outrageously impractical recipe for calculating a complete social minimum, especially considering that

04 See A. Marseald, PrIncrples of Economacs 124 (1890); Hicks, The Rehabilitation of Consumers' Surplus, 9 REV. ECON. STUDIEs 108 (1941), reprinted in READINGS IN WeLfare Econontres 325 (K. Arrow \& T. Scitovsky eds. 1969).

55 This ignores the claims of future generations and the associated notion of a "just savings principle," discussed at RAwLs 284-93. Like the oversimplification discussed in note 50 supra, this oversimplification seems allowable in view of our inquiry's limited purpose.

56 Among the qualifications and refinements required for full development of the foregoing argument, the following may be briefly noted:

First, to be precise we ought to speak of basic packages of interrelated needs and service levels, rather than collections of mutually independent basic needs and levels. The statement that I would give everything I had in return for treatment of my tuberculosis breaks down if all I have is just enough to eat. A more precise statement might be that I would give all I had to be both cured and fed. Again, how much shelter (in the form of artificial heat) I deem essential may depend on what diet and clothing are available to me; and how much education I deem essential might depend on what level of subsistence is assured me in any event. Thus there seem to be various sets of value-interchangeable basic packages. Cf. Tribe, supra note 6 , at 91-92. It would seem that in looking for that package whose provision will satisfy average utility we should focus on that package in each such set which is cheapest to produce.

Second, the discussion applies only to needs which in normal course would be satisfied by the expenditure of money. It has no obvious application to "goods" which normally one already has when born, such as limbs and organs; or to "goods" which are not materially costly to produce, such as bodily freedom and privacy. A discussion which may be plausible in regard to the former sort of goods may well seem bizarre when applied to the others.

Third, I believe that the notion of basic needs developed here is at least remotely akin to notions of rights being cultivated by professors Tribe, supra note 6 , and Charles Fried (in an unpublished paper). The notions have in common the supposition of "Iumpiness" and "groupiness" in the exchange schedules ("indifference curves") which show how an individual would trade off (or decline to trade off) various increments of some goods against various increments of others. 
the contents of the basic set of needs must undergo continuing redefinition to keep abreast of changes in total output, distribution, social practice, and "tastes." Ant And even disregarding its impracticality, what has been described is only a method for calculating a minimum, not a method for delivering it. While the calculation is hinged to specific needs, delivery might well be in unrestricted cash. The calculation proceeds from general assumptions about most people's perceptions of their basic economic priorities; but even if one thought that such general assumptions might be accurate enough to provide the best available approach to calculating the universal social minimum guaranty that would maximize total consumer satisfaction, one might still choose to make some or all distributions in cash so as to avoid unnecessary sacrifices of welfare in the cases of recipients whose actual priorities vary from those of the general model.

Given the difficulties of calculation, the elusive and presumptuous nature of the necessary suppositions, and the possible wastefulness of in-kind distribution, it seems unlikely that utilitarians would try to compose their entire social minimum by packaging various constitutional insurance rights. Yet some select members of the basic set of needs might seem so obviously universal and durable as to warrant recognition as insurance rights, were it not for the fundamental problem of principle already mentioned: under average-utility notions, transfers (no matter how calculated) are undertaken for the sake of a maximizing interest ascribed to the populace as a whole, and not for the sake of any acknowledged claim of justice or right on the part of the disadvantaged claimant as such. This being so, it is quite unclear why any policy favoring such transfers should be advanced in the guise of "rights"-meaning demands that are to be met despite an opposing legislative will-especially when it is supposed, as in "ideal theory," that the legislature is the authentic voice of a morally enlightened population. ${ }^{58}$

57 The idea that "minimum" levels of service to particular needs, below which a special sense of deprivation will arise, might depend on levels which prevail generally in the society need not rest on any un-Rawlsian notions about envy. (For Rawls' treatment of envy, see RawLs 143-44, 538.) Some needs-education is an obvious example-may have intrinsically competitive aspects. But beyond that, needs are subject to influence by acculturative factors quite discrete from envy. See McBride, supra note 15, at 998-99. These factors do not exert their influence only though psychic channels. A commonplace illustration concerns one's "need" for an automobile. Where private automobile ownership is prevalent, it may be expected that (1) general land-use patterns will reflect such prevalent ownership in a way that tends to increase distances between most residential areas and most work places, and (2) political pressure for social investment in public transportation will be depleted. Thus a private car may become, in practice, a critical factor in employability and in general mobility.

58 See text accompanying notes $90-98$ infra. 
More than anything else, what appears to distinguish the difference principle from that of average utility is that the former does establish distributive claims for the disadvantaged to press on their own behalf, and not simply as happenstance advocates for the general public interest. And so one turns to the possibility of extending the "basic set" method of defining and calculating a social minimum, or part of it, to the minimum implied by the difference principle. But this, it turns out, cannot be done. One can say that the differenceprinciple social minimum must be at least as large as the averageutility social minimum, because all changes designed to achieve the latter minimum must increase the bottom's income and all such changes are required by the difference principle. ${ }^{59}$ But this is not at all the same thing as saying that the difference-principle minimum could ever be calculated, even in part, by asking what particular needs the bottom was able to satisfy at various income levels. The special relevance of basic needs for average utility is that the abnormally high consumer's surplus they imply can overbalance the antiproductive effects of tax-induced disincentives so as to yield a net increase in total consumer satisfaction. But increases in consumer satisfaction, as such, hold no interest for the difference principle. That principle simply pursues any increase in the bottom's income, whether or not large enough to yield a net rise in consumer satisfaction in the face of tax increases and associated incentive and production losses. Incometransfer activity is simply to be intensified just up to the point where any further intensification lowers total output so much that the bottom's absolute income begins to fall even as its relative share of total consumer satisfaction continues to rise. Under the difference principle, that is all there is to it. There can be no implicit insurance-rights package because there is no concern for what the bottom spends (or is able to spend) its income on. Income is income-a primary, an elemental, social good, of which the bottom simply wants and is entitled to as much as it can get.

So we have arrived at this point: Under average utility there is a difficult argument for relating a social minimum to basic needs (or articulating a minimum in terms of social insurance for basic needs), but no argument for erecting the minimum so conceived into a constitutional right; whereas under the difference principle a right is surely implied, but it is a (less justiciable) income right rather than a (more justiciable) set of insurance rights.

69 This reflects the "maximin" rationale for preferring the difference principle over average utility in the original position. RAwLS 152-56. 
Even apart from the quest for justiciability, the position under the difference principle is unsatisfactory. A precept for the distribution of material social goods which ignores claims regarding basic needs as such, and is sensitive only to claims regarding money income, will for many of us seem incomplete and thus not fully in harmony with our "considered judgments." 60 And there are surface indications that this is true for Rawls himself, for his own references to the size of the social minimum equivocate between emphasis on needs and emphasis on holding down inequality. ${ }^{61}$ (One comes away with the impression that the minimum is to be set with a view both to assuring fulfillment of certain relatively basic needs and to accomplishing a desired, but highly contingent and ineffable, degree of income equalization.) We are obliged, then, to consider whether we have pressed the inquiry far enough.

60 It may be asked how anyone's considered judgments can be offended by a principle that demands the maximum possible income for the bottom, merely because that principle exhibits no concern for satisfying any particular needs the bottom may be supposed to have. If certain needs remain unsatisfied even after the difference principle is satisfied, nothing more can be done to meet them. How, then, can considered judgments be offended?

The answer is that a considered judgment is composed not only of a conclusion regarding the rightness of a given act or outcome, but also of a reason or reasons, however indistinct or inarticulate, for that conclusion. I further suggest that the reasons may have practical importance not only in indicating what is to be done in the particular case (if the conclusion is that correction is required), but also in conditioning our more general response to situations of that type.

Suppose a number of persons are seen to have incomes so low that they cannot obtain basic health care. Two observers might agree that the situation demands correction, but disagree about the reasons. The first may say that the observed inability of some persons to obtain health care out of private income is strong evidence that the difference principle is being violated. It is hard to know what remedial action he could demand except that the legislature, with such economic-policy advice as it can garner, immediately consider whether the bottom's income might not be raised by some means consistent with the liberty and opportunity principles. The necessary analysis is likely to prove time-consuming and complex. A decision to stand pat, on the ground that no increase in the bottom's income is in fact possible, will almost certainly not be demonstrably wrong. The first observer could strongly believe that it is wrong, without questioning the legislature's good faith. At this point, the first observer could make no further demands.

The second observer says that the existing situation is troubling not only because it suggests that the bottom's income is not as high as it could be, but also because persons are entitled not to be barred from basic health care by impecunity-recognizing as a natural limitation that the right is exhausted once it can be shown that the bottom's income is as high as it can possibly be, or that there is no way to free the health-care interest from the impecunity risk without displacing that risk onto some other interest deemed at least equally important. The second observer, then, can demand that the legislature enact a health-insurance program, and the burden of persuasion will then be on those who disagree to show that the natural limitation supports their position.

Thus the difference in reasons given for the same conclusion may have an important effect on attitudes with which the problem of correction is approached, and therefore on the legislative outcome; and this possibility exists although we assume, consistent with the suppositions of ideal theory, that the legislature always acts in good faith.

61 The "needs" factor is emphasized at RawLs 276-77. The "equalization" factor is apparent at $i d$. 285-86. It should be recalled that some amount of equalizing taxation will be undertaken for the sake of protecting fair equality of political liberty and of opportunity. Id. 277-79; note 32 supra. But this does not exclude further equalization for the sake of the difference principle, and certainly does not make the calculus more determinate. 
An obvious place to look further is into the notion of primary social goods. This notion's lack of articulation seemed in our discussion to play an important role in masking insurance rights out of a difference-principle social minimum. That discussion, of course, focused on the objective, material primary social goods of income and wealth. Perhaps we can get where we-and evidently Rawls, as well-would like to go by including the primary good of self-respect among those with respect to which the bottom's prospects are to be maximized.

Rawls defines self-respect as follows:

We may define self-respect . . . as having two aspects. First of all, ... it includes a person's sense of his own value, his secure conviction that his conception of his good, his plan of life, is worth carrying out. And second, self-respect implies a confidence in one's ability, so far as it is within one's power, to fulfill one's intentions. When we feel that our plans are of little value, we cannot pursue them with pleasure or take delight in their execution. Nor plagued by failure and selfdoubt can we continue in our endeavors. It is clear then why self-respect is a primary good. Without it nothing may seem worth doing, or if some things have value for us, we lack the will to strive for them. All desire and activity becomes empty and vain, and we sink into apathy and cynicism. Therefore the parties in the original position would wish to

' avoid at almost any cost the social conditions that undermine self-respect. ${ }^{2}$

I shall assume without detailed discussion that the notion of self-respect as a moral entitlement is perfectly capable of implying some conception of a minimum insurance-rights package. Rawls captures the essence of this view when he refers to a "psychological condition" in which "persons lack a sure confidence in their own value and in their ability to do anything worthwhile," and notes that

many occasions arise when this psychological condition is experienced as painful and humiliating. The discrepancy between oneself and others is made visible by the social structure and style of life of one's society. The less fortunate are therefore often forcibly reminded of their situation, sometimes leading them to an even lower estimate of themselves and their mode of living. ${ }^{63}$

But there is initial difficulty in feeding this view into applications of the difference principle, because by itself it does not seem to fit the difference principle's "more is better" attitude. The self-respect ap- 
proach to welfare rights most naturally seems to want to satisfy a minimum, not to get more and more. Such a difference between income and wealth, on the one hand, and self-respect, on the other, may be illustrated by the following graphs, in which the horizontal axes both measure intensity of tax-transfer activity (" $T$ ") and the vertical axes measure, respectively, the bottom's expectations regarding income (" $E_{g}$ ") and the bottom's expectations regarding selfrespect (" $E_{s}$ "). The relationship between $T$ and $E_{y}$ is depicted by a roof-shaped curve indicating that at lower levels of $T$ any disincentive effects are more than offset by the increase in the bottom's share, while the converse is true at the higher levels of $T .^{64}$ The top of the roof is the point where $E_{y}$ is maximized, and the difference principle

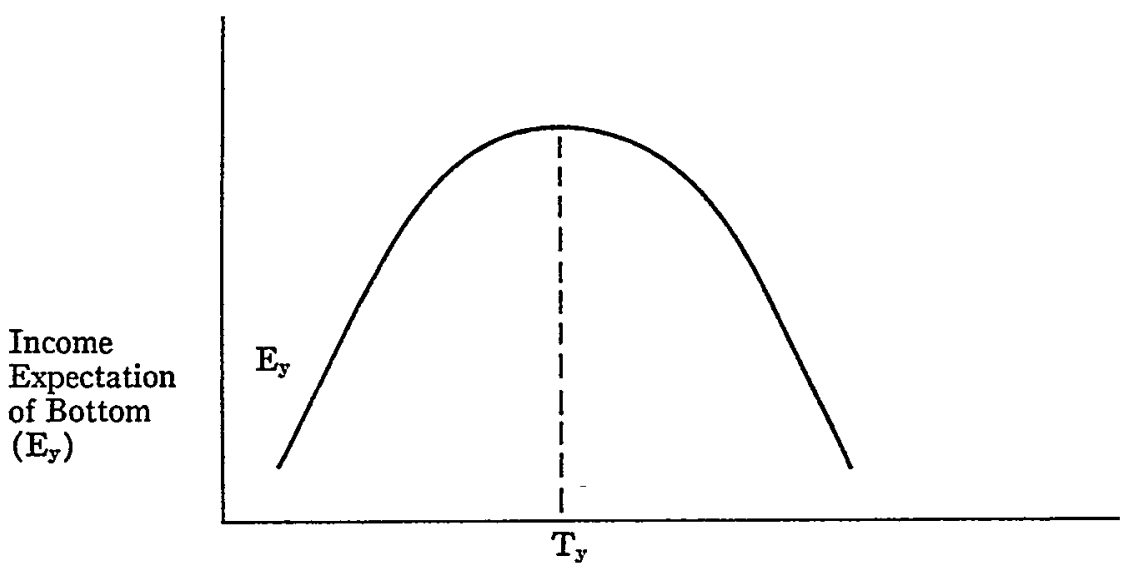

Tax-Transfer Activity ( $T$ )

coherently requires that $T$ be set at level $T_{y}$. The relationship between $\mathrm{T}$ and $\mathrm{E}_{\mathrm{s}}$ can only be shown as a horizontal line beginning where $\mathrm{T}$ is at level $\mathrm{T}_{\mathrm{5}}{ }^{65}{ }^{65} \mathrm{This}$ is the minimum $\mathrm{T}$ which can satisfy the income/

Self-Respect

Expectation of Bottom $\left(E_{\mathrm{s}}\right)$

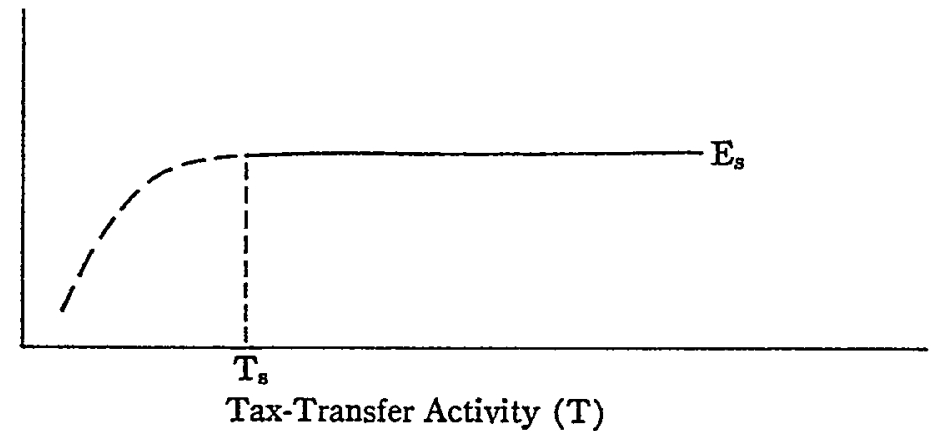

64 See text accompanying note 33 supra.

65 The descending tail to the left of $\mathrm{T}_{\mathrm{s}}$ is meant to allow for the plausible qualification that there is a rather narrow, "closing-in" range of provision for the bottom's basic needs 
welfare requirements of self-respect, and any additional $T$, while it might increase $E_{y}$ (if $T_{z}$ is less then $T_{y}$ ) can have no effect on $E_{g}$.

Rawls states that "in applying the difference principle we wish to include in the prospects of the least advantaged the primary good of self-respect; and there are a variety of ways of taking account of this value consistent with the difference principle." ${ }^{\text {66 }}$ But in fact he intimates only one way in which self-respect might be accounted for through application of the difference principle (though, as we shall see, there are clearly many ways of doing so without contradicting the difference principle). Rawls says:

To some extent men's sense of their own worth may hinge upon their institutional position and their income share. ... [But] with the appropriate background arrangements, [the] inclinations [to social envy and jealousy] should not be excessive, at least not when the priority of liberty is effectively upheld. But theoretically we can if necessary include self-respect in the primary goods, the index of which defines expectations. Then in applications of the difference principle, this index can allow for the effects of excusable envy [i.e., injuries to self-respect]; the expectations of the less advantaged are lower the more severe these effects. Whether some adjustment for self-respect has to be made is best decided from the standpoint of the legislative stage where the parties have more information about social circumstances and the principle of political determination applies. ${ }^{67}$

Rawls is, however, far from persuaded that any adjustment in the difference principle's application will ever be required in the interest of self-respect. ${ }^{68}$ And he does not give us any direct statement of what form such an adjustment could take. Self-respect aside, the difference principle has already, presumably, led to the setting of $T$ at level $T_{y}$.

within which the effect is to lift the bottom's self-respect some distance, but not as high as it might be lifted by income transfers. This possibility of a basic-needs-related selfrespect continuum seems to be recognized at RAwLs 546. Elsewhere, however, Rawls seems to differentiate self-respect, viewed as a satisficing kind of good, from income and wealth, viewed as a maximizing kind of good. Id. 396-97, 440, 543-44.

68 Id. 362.

67 Id. 546 .

$68 \mathrm{~A}$ need for such adjustments also to some extent mars the structural nicety of justice as fairness. Says Rawls:

[A]n equal division of all primary goals is irrational in view of the possibility of bettering everyone's circumstances by accepting certain inequalities. Thus the best solution is to support the primary good of self-respect as far as possible by the assignment of the basic liberties that can indeed be made equal, defining the same status for all. At the same time, distributive justice as frequently understood, justice in the relative shares of material means, is relegated to a subordinate place. Thus we arrive at another reason for factoring the social order into two parts as indicated by the principles of justice. While these principles permit inequalities in return for contributions that are for the benefit of all, the preId. cedence of liberty entails equality in the social bases of esteem. 
There is no way the bottom's real money income can be increased by any adjustment of $T$. The only available adjustment, and the one apparently implied by the quoted passage, is to increase $T$ to some level $\left(T_{s}\right)$ higher than $T_{s}$, such that the top's standard of living has been reduced to the point where the standard of enjoyment of basic goods available to the bottom, although lower than that available at $\mathrm{T}_{y}$, is relatively high enough to confirm its self-respect. The supposition must be that insofar as self-respect may be undermined by low standards of living, this is significantly a matter of relative deprivation.

So in suggesting that adjustments for self-respect may be required in the course of applying the difference principle, Rawls must be supposing the possibility of cases in which $T_{\mathrm{s}}$, perhaps suprisingly, is higher than $\mathrm{T}_{\mathrm{y}}$-in which a higher level of tax-transfer activity is required to exhaust the possibilities of confirming the bottom's selfrespect than would maximize its income. Still, someone might argue that $T$ should not automatically be set at $T_{B}$ rather than at $T_{y}$-that the question depends on whether the value of $E_{s}$ at $T_{s}$ (assuming that $E_{s}$ is zero at all levels of $T$ below $T_{s}{ }^{69}$ ) is enough to offset the amount by which $E_{y}$ at $T_{y}$ exceeds $E_{y}$ at $T_{s}$. This argument would be illustrated as follows:

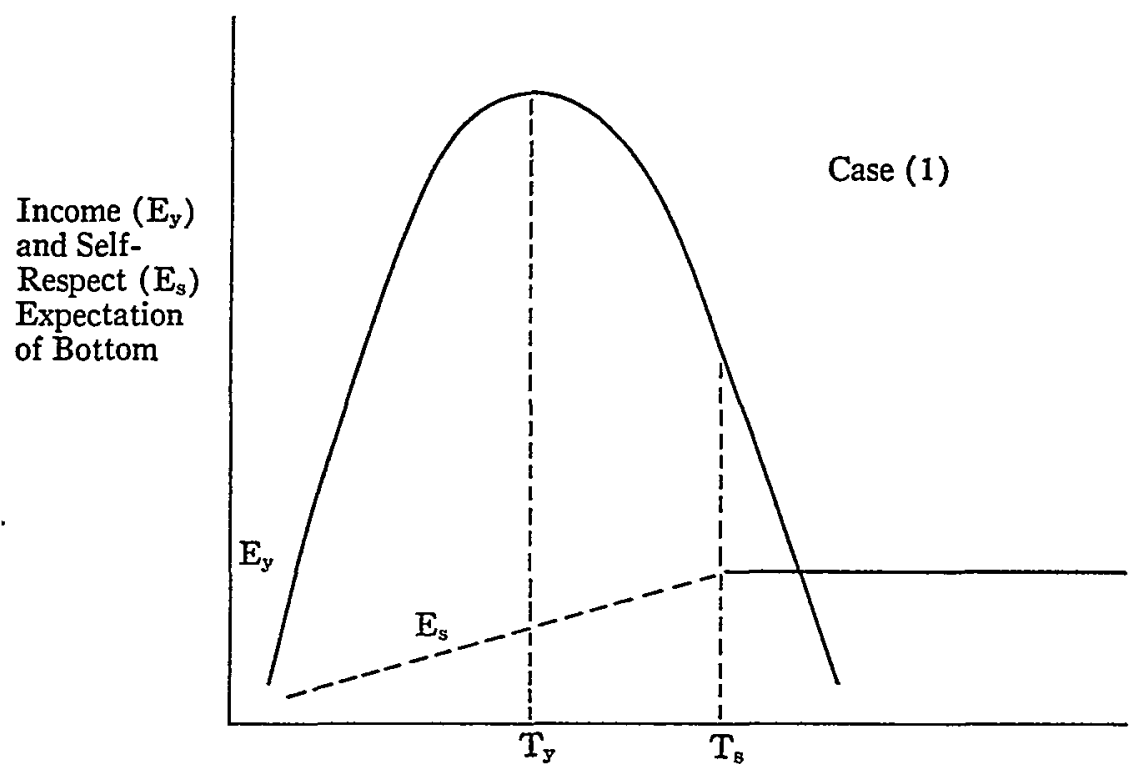

Tax-Transfer Activity ( $T$ )

In case (1), $\mathrm{T}$ must be increased so much to achieve the minimum (relative) standard of living for the bottom which will confirm 


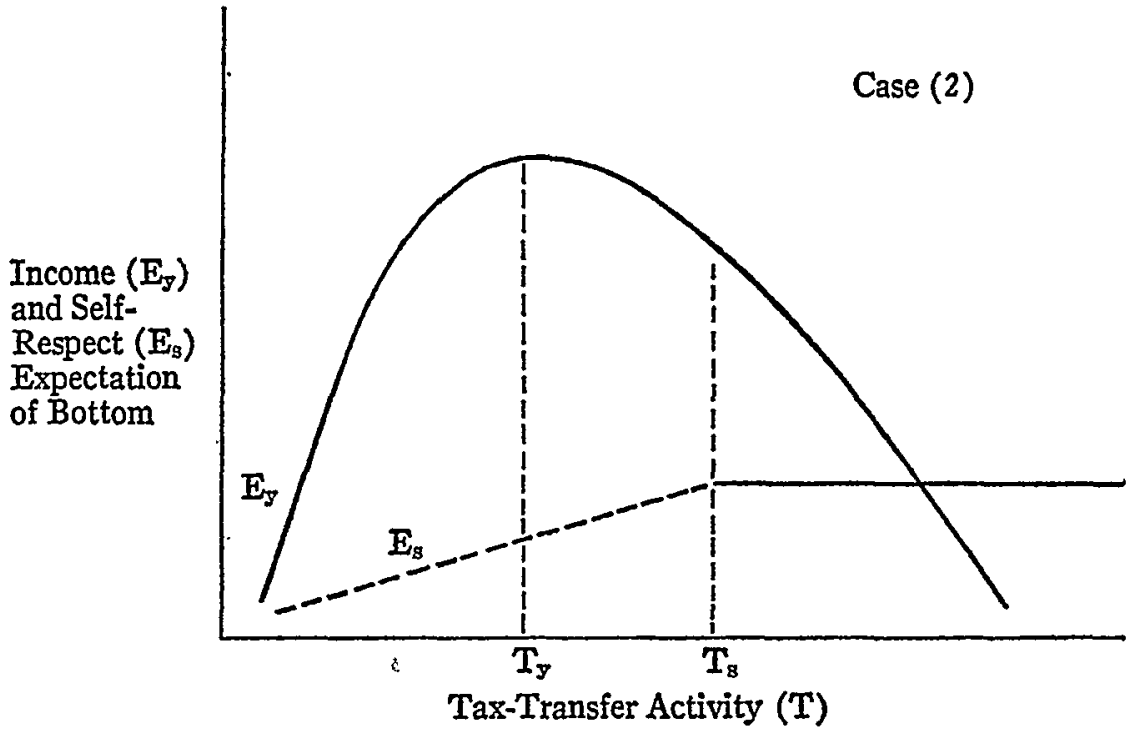

the bottom's self-respect that the "total" value of $E_{a}$ and $E_{g}$ at $T_{B}$ is less than the value of $E_{y}$ alone when $T$ is fixed at $T_{y}$. The opposite is true in case (2). But it is a mistake to treat $E_{y}$ and $E_{s}$ as mutually combinable and substitutable in this way. In the Rawlsian vision, income is virtually worthless without self-respect. ${ }^{70}$ So the question of adjusting the difference principle's application to take account of self-respect boils down to a conceptually simple idea: If it is necessary, in order to confirm the bottom's self-respect, to increase taxtransfer activity beyond the point where the bottom's income is maximized, we are to do so.

We have thus brought the satisficing good of self-respect within the maximizing structure of the difference principle, by showing that on its account maximization of the bottom's prospects may require tax-transfer activity which is suboptimal with regard to the bottom's income. In so doing, we have come as far as we can in pursuit of some implication in the difference principle of an insurance-rights package. Yet the quest has failed. Through a somewhat elusive notion of relative deprivation, we can see the possibility that an existing state of distribution might be perceived as unjust because of the bottom's inability to satisfy certain needs, considered in the comparative light of what others are able to enjoy. But there are only two possible remedies for such a situation. The preferred remedy, expected to suffice in most cases, is to raise the bottom's real income to

70 See RAwts 440 , 535. It is true that Rawls speaks in passing, id. 362, of assigning relative weights to self-respect and income in arriving at an index of the bottom's prospects. But this view seems so sharply at odds with the subsequent, more comprehensive elucidation of self-respect that it should perhaps be disregarded. 
the maximum achievable level. As we have already seen, ${ }^{71}$ there are no insurance-rights implications in that approach. An additional possible remedy - the one brought to light by the introduction of selfrespect as a primary social good-is taxation and transfer calculated to reduce both the top's and the bottom's real incomes, but to reduce the top's at a faster rate so as to narrow the relative-deprivation gap. But this is hardly a remedy that one would associate with the idea of insurance rights.

Though we have finished our exploration of the difference principle, we have not yet finished with the primary good of self-respect. Before continuing with our examination of it, ${ }^{72}$ it will be helpful to see what the opportunity and liberty principles might have to contribute to a notion of constitutional welfare rights.

\section{b. The Opportunity Principle}

This principle requires a degree of compensatory service to what we could call the "priming" needs of each individual, as by provision of basic education. Rawls does not say that any education must be publicly provided in kind, or that any compensatory right regarding education cannot be satisfied by general monetary transfers. But by attaching this right to the lexically preferred opportunity principle, Rawls must mean that it has to be satisfied before the difference principle can be allowed to operate-that compensatory satisfaction of the opportunity interest is a prerequisite to allowing any income inequalities to arise in the marketplace. It seems to follow that no one may be precluded from the requisite education by income shortage; and this would be, then, an insurance right. Even so, it might not generate a clearly justiciable claim unless its extent could be more precisely determined.

Now although the expression "fair equality of opportunity" seems to suggest an intuitionistic criterion of how far to cut into dispositive liberty on behalf of opportunity, the theory as a whole may give stronger guidance. Rawls believes his contractarian construct should generate assurances of educational offset for environmental accidents of background and upbringing, but not for genetic accidents of inheritance. ${ }^{73}$ This distinction may not defy translation into social policy. ${ }^{74}$

71 Text accompanying notes 43-60 supra.

72 Text accompanying notes $77-80$ infra.

73 Any further compensation for disadvantage in the natural-talents lottery is to be of the less-than-fully-offsetting type implied by the difference principle. See RawLs 73-75, 511.

74 See 1 Cal. Gen. Ass., Senate Select Compa. on Schoor District Finance, Final REPORT 39-43 (1962). 
If in the present state of educational technology it does not yield claims so determinate as to be justiciable, that it may someday yield them is perhaps not unimaginable.

The scope of welfare rights implied by the opportunity principle may not be limited to goods which are strictly "educational." Unaccompanied by subsistence or health or freedom from extreme environmental deprivation, how could educational offerings effectuate fair equality of opportunity? The priority of the opportunity principle over the difference principle and that of dispositive liberty must mean that education's effective biological entailments, whatever they are, must be satisfied as a prior condition to reliance on the pure procedural justice of the market-even supposing that such reliance would tend to maximize the bottom's real-income expectations, thus satisfying the difference principle. If so, the catalogue of welfare rights would reach beyond educational goods and (at least with regard to persons of educable age) into welfare domains which we tend to associate with the difference principle and the social minimum. And these additional rights seem more justiciable than the core education claim itself, and more justiciable under the opportunity principle than under the difference principle. It seems possible to arrive at somewhat objective and nonrelativistic descriptions of the levels of subsistence, health, and environmental amenity necessary to make persons receptive to educational offerings.

\section{c. The Liberty Principle}

Enjoyment of basic liberties, like enjoyment of educational opportunity, has fairly straightforward and objective biological entailments. Thus the right to provision of these may rank with liberty among the social priorities established by the theory of justice as fairness. Rawls so indicates when he says that the priority of liberty over satisfaction of material wants is not unqualified, that in some circumstances the lexically articulated conception of justice may have to give way to a "general conception" which permits trade-offs among all social values-liberty along with material goods-as long as those trade-offs satisfy the difference principle. ${ }^{75}$ This line of thought leads to a division of material wants into those which are and are not basic:

To be sure, it is not the case that when the priority of liberty holds, all material wants are satisfied. Rather these desires are not so compelling as to make it rational for the persons in the original position to agree to satisfy them by accepting a less than equal freedom.... Until the basic wants 
of individuals can be fulfilled, the relative urgency of their interest in liberty cannot be firmly decided in advance. It will depend on the claims of the least favored as seen from the constitutional and legislative stages. But under favorable circumstances the fundamental interest in determining our plan of life eventually assumes a prior place. ${ }^{76}$

\section{d. Justice as Fairness as a Whole}

The good of self-respect seems to play a dual role in the theory of justice as fairness. It is, as we have seen, one of the primary goods, along with income and wealth, with respect to which the difference principle demands that the bottom's prospects be maximized. In this role self-respect may be said to be coordinate with income and wealth $^{77}$ and subordinate to rights and liberties, in the lexicon of primary social goods. But there is another perspective in which confirmation and nurture of self-respect are the end and objective of all the principles of justice taken together. In this perspective, selfrespect is the preeminent social good, superordinate even to rights and liberties. The liberty principle, the opportunity principle, and the difference principle - each separately and all in their convergent impact -are elaborated and justified in terms of their tendency to instill and safeguard self-respect; and insofar as it is feared that one or another of these principles in isolation may be insufficiently solicitous of self-respect, it is shown how one or another of the other principles may counteract this concern. ${ }^{78}$ Self-respect thus becomes a central element in the justification of the whole theory.

It follows that if welfare rights can be shown essential to selfrespect, in any sense additional to those in which the difference, opportunity, and liberty principles severally imply such rights, the theory of justice as fairness implies them in this additional sense as well. Thus the difference principle implies welfare rights in the elusive form of whatever is necessary to prevent the undermining of self-respect by relative deprivation. The opportunity and liberty principles imply welfare rights as more objective, less relativistic biological entailments of opportunity and liberty. In addition, the central and preeminent good of self-respect may imply welfare rights reaching beyond those biological entailments, and not depending on notions of relative deprivation for their justification. Perhaps, for example, self-respect requires the opportunity to be creative in some medium which gives

76 Id. 543.

77 But more precisely it seems to be a condition of the enjoyment of income and wealth. See text accompanying note 70 supra.

78 See Rawss 534-48. 
pleasure to others - artistic performance, crafts, sport, or whatever ${ }^{79}$ though perhaps no one would say that he was degraded by not having had such opportunities, or that his educational offering or civil and political liberties were rendered worthless without it.

Professor Fried has suggested that it would be possible to "[elaborate] a comprehensive theory of rights within the terms of Rawls' general scheme." that this is indeed possible for welfare rights, although it seems to require some verbal modification of the "general scheme" of lexically articulated principles of justice. Somewhere near the top of the priority list there belongs a "welfare rights" principle, signifying that the questions of maximizing the bottom's position with regard to money income and wealth, and even of protecting the bottom against the degrading effects of relative deprivation, are simply not to be addressed until provision for some articulated package of basic welfare needs has been secured.

In sum, it is a mistake to think of the social minimum as an institutional feature linked specifically and peculiarly to the difference principle (whereas democracy or a bill of rights, say, would be associated with the liberty principle). The social minimum is an implication of justice as fairness taken as a whole theory. While the difference principle taken in isolation seems to have a simple, maximizing thrust, that is not true of the whole theory. The theory as a whole reflects a degree of risk aversion, imputing to representative persons a structured set of priorities under which the question of generally amplifying one's income simply is not reached until adequate assurance has been made for what one specifically needs in order that his basic rights, liberties, and opportunities may be effectively enjoyed, and his selfrespect maintained.

\section{B. Judicial Role}

The principles of justice as we have been exploring them are part of an ideal theory of justice as fairness. The ideal, to which an appropriate conception of justice is to be wedded, is that of a "well-ordered society"- "one designed to advance the good of its members and effectively regulated by a public conception of justice," ${ }^{81}$ or, as Rawls sometimes says, one which is in "a state of near justice." part of the argument for justice as fairness is that it meets the test

79 See id. $440-42$.

80 Fried, Book Review, 85 HaRv. I. Rev. 1691, 1697 (1972).

81 RawLs 453. See generally id. 453-62.

82 Id. 351. 
of stability-that when constitutional and statutory arrangements, and the institutions they help to shape, are seen to conform to the principles of justice they will, by virtue of that conformity, command the continuing, mutually reinforcing support of a citizenry whose members perceive both one another's acknowledgment of the principles and the inclination of their shared institutions to conform. ${ }^{83}$ The essential point here, for our purposes, is that the principles of justice are chosen and tested, for stability as well as other qualities, on the supposition of $a$ society which is well-ordered with respect to those very principles. This is ideal theory. "[J] ustice as fairness is framed to accord with [the] idea of [a well-ordered] society." societal system, once publicly founded on the principles of justice, will then be in a stable equilibrium state which is good for its members.

Now one may ask whether this ideal conception of justice in a well-ordered society has any place for the "judicial review" part of our traditional model of the constitutionalized legal order. In ideal theory, constitution-making is a hypothetical step in contractarian derivation of procedures and rules for a society supposed to be wellordered. We assume that the veil of ignorance worn in the original position has been lifted to the point where participants in the constitutional convention have knowledge of the basic traits of their society, such as its material wealth, technological capabilities, sophistication in economic and sociological matters and the like-what we could call the society's "evolutionary circumstances." The particular situations and traits of the parties remain, as in the original position, unknown to them. In this contextually enriched forum the framers choose rules and practices, somewhat more specific than the principles of justice, designed for optimal implementation of those principles in their society. ${ }^{85}$

There is no doubt that a constitution thus fashioned for a wellordered society might set up an independent magistracy and fence it out of the legislative domain, to provide a neutral and politically detached forum for settling disputes over the meaning of legislatively approved legal rules and principles, and for assuring their fair and

83 See id. 4-5, 138, 454-55.

84 Id. 454.

Best of all, a theory should present a description of an ideally just state of affairs, a conception of a well-ordered society such that the aspiration to realize this state of affairs, and to maintain it in being, answers to our good and is continuous with our natural sentiments. A perfectly just society should be part of an ideal that rational human beings could desire more than anything else once they had full knowledge and experience of what it was.

Id. 477 (footnote omitted).

85 See id. 196-97, 200. 
nondiscriminatory application. ${ }^{86}$ But it is far less clear whether or why such a constitution would give a judicial branch authority to enforce, against the will of the legislative branch, either "natural rights" ${ }^{\prime 87}$ or constitutional rights which directly and visibly implement natural rights.

In ideal theory, the original position and the constitutional and legislative stages are distinguished from one another only by the amount and specificity of information supposed to be available about the society and its problems and needs-and, accordingly, the appropriate level of generality for the promulgated rules, practices, and institutional arrangements. ${ }^{88}$ Ideal framers are seen as none other than the imaginary "representative persons" of the original position, who have simply shifted their discussions over to the constitutional stage, having once agreed on the governing principles of justice and received information about their society's evolutionary circumstances. ${ }^{89}$ Rawls seems to think of ideal legislators as persons actually chosen for this office under the procedures approved at the constitutional stage. ${ }^{90}$ But their behavior should be no different than if we imagine them to be the same set of law-givers, now twice removed from the original position and exposed to the fuller information appropriate to the legislative stage. Consistent with the assumption, arguendo, of a society wellordered with regard to the principles of justice, and with the fully argued position that those principles are stable, it appears that ideal legislators must tend to act in such a way as to make judicial review superfluous.

The argument for the stability of justice as fairness explicitly rejects any notion of the legislative system as a "fairness machine" deliberately constructed so as to harness, in market-like fashion, the selfish drives of legislators and their constituents in such a way that the vector sum of these drives corresponds with something we are pleased to call the (or a) "public interest." (Had that been the approach, one might have speculated as to a role for judicial review

86 See id. 238-40.

87 I am using the term "natural rights" to mean rights implied by principles of justice in a coherent philosophical theory of justice.

88 See RawLs 198-99.

80 See id. 196-97.

90 See id. 198, 356-58.

91 For discussion of this concept, see Michelman, Property, Utility, and Fairness: Comments on the Ethical Foundations of "Just Compensation" Lav, 80 HARv. L. REv. 1165, 1246 (1967).

02 See RAwrs 359-61, 493, explaining that a "fairness machine" is not operative. For a contrasting view of society that would have to rely on a fairness-machine notion, see id. 455, 521-22. For one extended development of such a notion, see A. Dowss, AN Econosic TemorX of DeMocracy (1957). 
on occasions of more or less obvious breakdown of the fairness machine.) ${ }^{93}$ And Rawls shows no affinity for the related idea of a division of labor between legislature and reviewing court, in which it is the special virtue of the legislature to be a forum for the vigorous free play of interests groping towards optimal accommodation, and of the court to be a kind of superego, backstopping the process when its vigor and enthusiasm carry it beyond the established bounds of constitutionalized moral principle..$^{94}$ Rather, Rawls argues strenuously that, given a society well-ordered with regard to his proposed principles of justice, the resulting sense of justice of legislators and their constituents-and their perception that it is consistent with their good that they should have this sense-will work effectively to keep the system on course. ${ }^{95}$

The claim is not that there will never be legislative deviations from what perfect justice, perfectly understood, would dictate. The method of moral argument indicated by the criterion of "stability" accepts an opposite assumption that the proposed principles of justice will sometimes be violated even in an ideally constituted regime. It is from that assumption that the moral theorist then proceeds to support his favored principles by showing how strongly their public recognition will tend to engender in the populace a sense of justice which, in turn, will work to ensure that the inevitable legislative deviations will be temporary. ${ }^{96}$ Civil disobedience may be regarded as the most dramatic manifestation of the stabilizing public sense of justice. ${ }^{97}$ Less dramatic, but more germane for our purposes, is the simple notion that ideal legislators themselves are citizens, animated no less than others by the sense of justice. They are, accordingly, expected to engage in mutual discussion and pooling of judgments about what is just and (secondarily) efficient under the circumstances. Votes are counted, and the majority rules, only because in problematic situations that is thought not a bad way to arrive at sound judgments, and because that procedure is consistent with the liberty principle's demand for equal participatory rights. ${ }^{88}$

93 For example, consider the notion of "invidious classifications" discussed in Michelman, supra note 17, at 19-20.

94 For a more complete articulation of this idea, see A. BICKEI, THE LEAST DangerOUS BRANCH 24-26, 95 (1962).

95 See Rawls 493.

96 See id. 458.

${ }^{97}$ See id. 364-68.

98 See id. 356-62. The need for majority rule as distinguished from the principle of unanimity which governs the original position and, presumably, the constitutional stage arises from the greater richness of factual context at the legislative stage.

The restrictions on information [applicable at the legislative stage; i.e., the ideal

legislator is supposed to be ignorant of his particular situation in society] will 
Now once the possibility is conceded of legislative error and disturbance of equilibrium, even in a well-ordered society, we may ask whether a role is not thereby opened for judicial review-that is, the role of calling attention to and demanding correction of mistakes when they do occur, of activating the temporarily lapsed sense of justice and catalyzing the process whereby that sense regains control. The question, particularly acute in the case of welfare rights, is why we should suppose that occupancy of judicial office will reflect any special ability to perform this role. Surely Rawls is correct when he writes that even in ideal circumstances,

judgment [regarding economic and social policies] frequently depends upon speculative political and economic doctrines and upon social theory generally. Often the best that we can say of a law or policy is that it is at least not clearly unjust. ... It is often perfectly plain and evident when the equal liberties are violated. ... But this state of affairs is comparatively rare with social and economic policies regulated by the difference principle. ${ }^{99}$

Thus it may be doubted (and Rawls doubts) ${ }^{\mathbf{1 0 0}}$ that, under the informational constraints of the constitutional stage, welfare rights could be articulated prudently at that stage with much greater specificity than that already contained in the principles of justice themselves; and, if not, that judicial officers could contribute anything worthwhile to recognition and articulation of such rights at the legislative stage.

The argument against judicial review for welfare rights (in ideal theory) is yet stronger than this. While the gains to be expected from this institution are unclear, certain costs are clear. The right to maximum mutual political liberty implies a democratic form of government

not guarantee agreement [as in the prior stages], since the tendencies of the Id. 357 .

general social facts will often be ambiguous and difficult to assess.

90 Id. 199. Though Rawls speaks here of "policies regulated by the difference principle," the context suggests that we should understand him as meaning to include all policies regarding the social minimum-a notion which, as we have seen, is best regarded as regulated by the theory of justice as a whole rather than peculiarly by the difference principle. See text accompanying notes 77-78 supra.

100 Rawls

imagine[s] . . a division of labor between stages in which each deals with different questions of social justice. This division roughly corresponds to the two parts of the basic structure. The first principle of equal liberty is the primary standard for the constitutional convention. Its main requirements are that the fundamental liberties of the person and liberty of conscience and freedom of thought be protected and that the political process as a whole be a just procedure. ... The second principle comes into play at the stage of the legislature. It dictates that social and economic policies be aimed at maximizing the longterm expectations of the least advantaged. . . . At this point the full range of RAwLS 199. 
in which the legislature is either composed of or accountable to the citizens, and decisions are made according to majoritarian processes. ${ }^{101}$ Rawls does not accept the view that "the political liberties are of less intrinsic importance than liberty of conscience and freedom of the person," or that "the chief merit of the principle of participation is to insure that the government respects the rights and welfare of the governed." ${ }^{102} \mathrm{He}$ argues, rather, that equal political liberty is valued and enjoyed in its own right, that it "strengthen[s] men's sense of their own worth, enlarge[s] their intellectual and moral sensibilities, and lay[s] the basis for a sense of duty and obligation upon which the stability of just institutions depends." ${ }^{\prime 103}$ Judicial review introduces a sharp and clear inequality of political voice (concerning what the principles of justice or their constitutional derivatives require in a given situation), and so can be justified, under the first principle, only insofar as it works to maximize the total system of liberties enjoyed by those accorded the lesser voice (i.e., the nonjudges). ${ }^{104}$ While Rawls acknowledges that plausible arguments in this form can be made (drawing on traditional arguments for bills of rights, concern over majority tyranny, etc.), he seems inclined to the view that these arguments should be treated most circumspectly for a well-ordered society. ${ }^{105}$

The foregoing considerations should help us grasp what Rawls' means when he insists that the question of justice and right is to be held apart from the question of legality. A system which is wellordered, and just on the whole, may on particular occasions act in ways which we are convinced are in themselves unjust. On some of these occasions, refusal to abide by the law may be appropriate. Indeed, the readiness of persons to engage in, say, civil disobedience on appropriate occasions, and the potential efficacy of this conduct, may be a part of the overall makeup of the society which leads us to call it well-ordered-an important stabilizing element which avoids the affront to equal liberties inherent in judicial review. But mostly the overall justice of the system makes it reasonable to expect that a just person will abide by occasional failures of justice. This expectation is a third factor which, combined with belief in the efficacy of the public sense of justice and the tendency of judicial review to undermine equal liberties, suggests that the better-ordered the society is

101 See id. 221-23, 227.

102 Id. 229-30.

103 Id. 234.

104 See id. 229-30.

105 See id. 231-34. But see id. 224, 229. 
supposed to be, the less interested we become in the question of judicially enforceable constitutional rights, especially welfare rights. And so, insofar as the theory of justice as fairness is simply an expression of Rawls' understanding of what a well-ordered society would be like, we should not expect him to be greatly troubled by the theory's questionable ability to generate justiciable welfare rights.

\section{Nonideal Theory: From Natural Right to Positive Entitlement}

Of course Rawls' effort to develop an ideal theory of justice is not intended as completely idle speculation. The ideal theory and its counterpart conception of a well-ordered society are meant to define a state toward which we should want to move. They "set up an aim to guide the course of social reform."106 And so there is need-to which Rawls does not generally purport to address himself-for "nonideal" theory to account for the role of justice as fairness in a society which is not fully and maturely just-a society whose members do not yet generally and publicly acknowledge the principles of justice, or whose material circumstances, or political and social maturation, have not yet reached a point admitting full implementation of the principles. ${ }^{107}$ Judicially protected substantive constitutional rights seem intuitively as plausible in nonideal theory as they are dubious in ideal theory, although only in passing does Rawls seem to think of the constitution in this way. ${ }^{108}$ As we have seen, he offers a professedly stylized view of the constitutional convention as a hypothetical step in contractarian derivation of procedures and rules for a well-ordered society-that is, as a part of ideal theory. ${ }^{109}$

Of course, a society's evolutionary circumstances as disclosed to the constitutional convention may be such that the society is in or verging on a well-ordered state, but what if they are not? What are the framers to do if one of the evolutionary circumstances disclosed to them is that the society's members presently fail to understand, acknowledge, and feel confident of other people's understanding and acknowledgment of those principles of justice to which the convention members themselves are committed by virtue of their recent encounter in the original position? Under such conditions the full and immediate implementation of the principles might be impossible, and oblique and imperfect forms of implementation might hasten the process whereby

106 Id. 245.

107 See id. 245-46.

108 See id. 246-47.

109 See text accompanying notes 84-90 supra. 
their acceptance increases, and the public sense of justice implants itself. Thus the framers of the constitution might look toward rules and practices which produce some optimum mix of actualizing justice for the members of the present generation and hastening its fuller realization for future generations. They would then be seeking institutional arrangements which could realize (or improve the chances of realizing) certain rights even in the face of legislative hostility or apathy, and which also could proclaim rights and principles of justice in such a way as to advance their public acceptance. Because the parties would be in circumstances requiring optimization (i.e., tradeoff), they might agree to sacrifice some of the rights which would be theirs in a perfectly just society, or some aspects of these rights, including rights to maximum equal political voice, for the sake of realizing other rights.

We can approach the problem of optimization by way of Rawls' treatment (scattered through various parts of the book) ${ }^{110}$ of the case in which a society's state of economic development is so primitive that it cannot produce enough to satisfy everyone's basic wants-those which have to be satisfied before it makes sense to talk of enjoyment of any liberties, much less of equal liberties. ${ }^{111}$ To the extent that such conditions make impossible the full and immediate realization of the principles of justice, and especially the priority of the equal liberties, they permit relaxation of the lexical priority rules-relaxation which may lead all the way back to the "general conception" of justice consisting of the difference principle alone. ${ }^{112}$ Specifically, equality of political voice may be suspended. "[I]t may be reasonable to forego [this equality] when the long-run benefits are great enough to transform a less fortunate society into one where the equal liberties can be fully enjoyed."113

Does parallel reasoning hold when it is underdevelopment of the society's sense of justice, rather than of its productive capacity, which makes impossible the full and immediate realization of the principles of justice? If so we might have isolated the germ of a Rawlsian account of substantive constitutional rights and judicial review.

But matters are not so simple. The cases of economic and moral underdevelopment stand quite differently with respect to the stipulations governing the original position. On the one hand, knowledge of the society's material circumstances is specifically withheld from the

110 E.g., RawLs 247, 300-01, 542-44.

111 See id. 543.

112 See text accompanying note 75 supra.

113 RawLs 247. 
parties; and this is why a sliding-scale conception of justice emerges which is adaptable to the whole imaginable range of such circumstances -proposing a rather firm set of priority rules for societies beyond a certain level of material comfort, a simple general conception for societies below a certain level of poverty, and, by implication, a continuous series of progressively relaxed priority systems for societies in intermediate stages. On the other hand, it is expressly stipulated that "in assessing conceptions of justice the persons in the original position are to assume that the one they adopt will be strictly complied with. The consequences of their agreement are to be worked out on this basis."114 Should it later be disclosed to the parties, now acting as a constitutional convention, that this assumption does not hold for their society, one might think they have no choice but to disband. The only principles they have available for appraising proposed constitutions are, it turns out, partly based on a false assumption.

Yet it would be grotesquely trivializing to regard ideal theory as relevant only for societies already verging on perfection as defined by its precepts. The assumption of strict compliance is a part of the method proposed for deriving principles, not a restriction on the relevance or applicability of whatever principles are derived through the method. On the contrary, the very purpose of deriving the principles must be to help us clarify our notions of what is to be done when the strict-compliance assumption fails.

So, for illustration, if the assumption fails at the legislative or postlegislative stage, Rawls contemplates corrective measures appropriate to that stage, such as civil disobedience. And if the assumption should fail at the constitutional stage - if the information appropriate to that stage should disclose a failure of the assumption-there seems no reason not to consider the introduction of corrective measures at that stage. Plausible correctives would include substantive constitutional rights and judicial review. ${ }^{115}$

But to consider does not necessarily mean to embrace. Substantive rights and judicial review, though plausible devices for coping at the constitutional stage with underdevelopment of the public sense of

114 Id. 145.

115 The analogy may seem imperfect insofar as we regard effective civil disobedience as a manifestation of well-orderedness rather than as a device for coping with its absence. Compare text accompanying note 97 supra with text accompanying note 105 supra. Yet on inspection this symptomatic view of civil disobedience seems to mean simply that it is only in societies where the public sense of justice has passed a certain level of development that we should expect to see resort to this device or think it appropriate or potentially effective. We shall find it possible to offer similar statements about substantive constitutional rights. 
justice, may on close examination be found unacceptable, or acceptable only within rather strict limits.

The case for judicial review remains harder than that for relaxing the priority of liberty in the face of material shortage. A society which cannot produce enough to satisfy everyone's basic wants is, by definition, not a society in which "equal liberties can be fully enjoyed."116 For that reason, it is not ultimately repugnant to the priority of liberty to allow severe or unequal restrictions of liberty now, if these measures are found necessary to boost productivity to the point where full and equal liberty can be truly realized later. Only in a superficial sense can one even say that the priority of liberty is relaxed in this case; at a deeper level, that priority is fully respected. ${ }^{117}$

Now once a material base sufficient to satisfy everyone's basic wants is assured, and only a deficient public sense of justice impedes full realization of the principles, is there still room to argue that equal political liberty may be restricted (by judicial review, for example) for liberty's sake? The argument is plausible insofar as judicial review would be singularly effective in realizing basic liberties (e.g., rights to free speech and equal voting) or rights to the fulfillment of everyone's basic wants on which enjoyment of these liberties depends. But use of judicial review to vindicate welfare rights not strictly associated with the basic liberties ${ }^{118}$ would flatly contradict the priority of liberty. Once the basic liberties and their effective enjoyment have been assured to all, justice as fairness might well insist that all other claims gain recognition in the participatory forum. Should it be the case that the requisite public sense of justice is currently lacking, it may also be the case that entrusting its nurture to judicial review will, paradoxically, indefinitely stunt the growth of this sense. The answer depends on the facts of human psychology, and the notion of the priority of liberty reflects a view of those facts which cautions against judicial review. Equality of political participation, it bears repeating, "lay[s] the basis for a sense of duty and obligation upon which the stability of just institutions depends." "119 Moreover,

as the conditions of civilization improve, the marginal significance for our good of further economic and social advantages diminishes relative to the interests of liberty, which become stronger as the conditions for the exercise of the equal freedoms are more fully realized. . . . Increasingly it becomes

116 See text accompanying note 113 supra.

117 Rawls regards the parties in the original position as speaking for "continuing lines of claims," or "as representatives of families." RawLs 128.

118 See text accompanying notes 72-75 supra.

119 See text accompanying note 103 supra. 
more important to secure the free internal life of the various communities of interests in which persons and groups seek to achieve, in modes of social union consistent with equal liberty, the ends and excellences to which they are drawn. In addition men come to aspire to some control over the laws and rules that regulate their association, either by directly taking part themselves in its affairs or indirectly through representatives with whom they are affiliated by ties of culture and social situation.

... [Material desires beyond the basic wants] are not so compelling as to make it rational for the persons in the original position to agree to satisfy them by accepting a less than equal freedom. ... One reason for this ... is the central place of the primary good of self-respect and the desire of human beings to express their nature in a free social union with others. ${ }^{120}$

Yet we must not forget that welfare rights, even those reaching beyond fulfillment of basic wants, also have a role in promoting the self-respect in whose absence the sense of justice will not flourishthe same self-respect, indeed, that the equal liberties are meant to serve. $^{121}$ There may, then, be a role for constitutionalized welfare rights even after it appears that everyone has, so to speak, enough to eat. So there we have the uneasy case for judicially enforceable, substantive constitutional rights as a means of coping with evolutionary deficiencies in the public's sense of justice. In order to secure the enforcement of certain rights, all looking ultimately to self-respect, the framers might be prepared to sacrifice some of their rights of equal political liberty by authorizing politically aloof courts to override the popular legislative will. If so, the foregoing discussion shows that they would certainly try to limit that sacrifice by insisting that any such interventions be convincingly supportable by argument appealing to widely shared premises.

The framers might try to write all such premises specifically into the constitution (as in a bill of rights). Or they might also permit the reviewing judges to invoke such other precepts as are found latent in popular morality. Revealing, clarifying, and rationalizing such latent moral principles might be deemed an important part of the court's work. Judicial review of the latter sort seems to carry greater threats to the self-respect cherished by the equal-liberty principle than review strictly anchored to specific constitutional texts. So even if the latter sort of judicial review were permitted, the framers would 
try to minimize any harm to self-respect by making premises explicit in the constitution when they could. And the resultant constitutional statement of rights would be in a form (say, of insurance rights) which might depart from what the ideal theory would imply in a wellordered society in which judicial review was not important.

If a given society's public sense of justice appeared to the constitutional convention to be so underdeveloped that judicial review of legislation action would on the whole advance the cause of justice, the convention could not expect that there would be, at the legislative stage, much convergence of judgment on the size or makeup of the just social minimum, or much hope for arguing persuasively that persons were receiving less than the minimum, or much reason for confidence that the legislature by itself would satisfy the minimum requirement. ${ }^{122}$ But the parties to the constitutional convention would not want to give up completely their welfare claims. They might want to create justiciable rights which would go a significant distance toward fulfilling those claims. And even apart from their reliance on judicial review, they might want to state some welfare rights in a form which could provide a ground for persuasive argument in political forums at an evolutionary stage in which popular perceptions and judgments about distributive-share justice were still rather clouded; such rights would serve as surrogates for the elusive claim to a proper social minimum. Moreover, the framers would be concerned to establish a political regime which would be reasonably workable-one which could know when it has satisfied the background conditions of distributive-share justice, and visibly seem to have satisfied them, so as to be justified in turning to other matters. Thus the framers might resort to a rather specific catalogue of wants (on the order of decent food and shelter, health care, a basic education, and effective access to judicial forums) which they could with reasonable certainty agree would have to be satisfied (given what they know about their society's economic circumstances and social and political development). That is, they might at the constitutional stage be able to agree that the social minimum would provide everyone with at least enough to assure satisfaction of certain wants, even if they could not agree how much more or what else was in justice required.

In order that these rights might gain effective support from a publicly acceptable form of judicial review and from convincing advocacy in political forums, the framers might choose to state them as insurance rights rather then as assurances of economic opportunity 
(and general transfer programs) sufficient to fulfill important needs as and when they accrue. Assurances of the latter sort, though preferred in ideal theory ${ }^{123}$ and perhaps also superior from the standpoint of efficiency, would hold no particular attraction at the constitutional stage in our supposed nonideal situation; for they would give neither courts nor advocates any special foothold for challenging legislative judgments. If a list of insurance rights did emerge, it might be a good deal less specific as to service levels than as to types of needs. For reasons to be developed below, the framers might believe that interplay between the legislature and the courts would tend towards satisfactory service levels, once the constitution had triggered the attention of both branches to the types of needs in question.

\section{The Place of Moral Philosophy in Constitutional Adjudication}

Two features of the suggested nonideal account of substantive constitutional rights and judicial review deserve emphasis: First, the account does not purport in any way to be an historical version, even a stylized or Procrustean one, of how written constitutions, substantive -rights, and judicial review have actually evolved. It is, rather, an explanation in principle of how these institutions may, in terms of a certain theory of justice, be harmoniously understood and related to other extant institutions and, more critically, to supposed underlying ends (such as democracy and self-respect) with which judicially enforced substantive rights may sometimes seem discordant. Second, this is on its face an account only of why a certain class of guaranties might be written into a constitution, in contemplation of possible vindication by such means as judicial review and legislative advocacy. It does not fully specify the guaranties that should be included, or treated as if included when they are not, although our exploration of the substantive welfare content of ideal theory ${ }^{124}$ may provide some clues.

An account of this sort may have practical and evaluative import for current legislative and judicial behavior. For, I believe, this behavior and our understanding of it are conditioned primarily by a need for contemporary coherence and comprehensibility, and only secondarily by historical reconstruction of the framers' intent. ${ }^{125}$

123 See note 43 supra \& accompanying text.

124 Text accompanying notes $21-80$ supra.

125 Why do we or should we try to reconstruct what the framers had specifically in mind, in the course of deciding what we are now to make of the texts they wrote? Is it not because we think that in the process of attempting such reconstruction we 


\section{A. Moral Theory as a Direct Source of Rights: The Case for Judicial Restraint}

Let us, heroically, suppose ourselves satisfied that Rawls' theory of justice as fairness suggests certain constitutional welfare rights as a way of doing justice in a society generally structured as ours is and in like evolutionary circumstances; that the theory further implies an institution of judicial review competent to demand fulfillment of at least some substantive rights; and, finally, that the theory ultimately succeeds in justifying itself in terms of coherence with moral views that we can confidently say are those of the society at large-that is, it persuasively accounts for and lends harmonious meaning to the generality of the society's public institutions and practices, including constitutional texts and traditions and other official and popular expressions of goals and ideals. ${ }^{126}$ Given those suppositions, are we to

shall often encounter clues and reminders of principles and notions (perhaps the only principles and notions) which can set those texts in coherent and comprehensible relation to one another and to the whole set of arrangements under which we continue to live, but whose informing ideas we sometimes lose sight of? Insofar as that is our quest, nonhistorical accounts would seem to have a competitive claim on our attentions, according to their felt explanatory power.

126 E.g., Housing Act of 1949, 42 U.S.C. §§ 1441-43 (1971). "The Congress hereby declares that the general welfare and security of the Nation and the health and living standards of its people require... the realization as soon as feasible of the goal of a decent home and a suitable living environment for every American family . . ." Id. $\S 1441$.

Professor Feinberg's lucid description of the "coherence logic of ethical justification" will serve well at this point to remind us of what Rawls, as a "coherence theorist," is up to:

[Coherence theorists] do not believe it possible to base an ethical system on self-evident moral first principles, or on direct intuitive insight into, or rational apprehension of, a uniquely moral realm of truth. Nor do they think it possible to deduce moral first principles from statements of fact, making no challengeable moral assumptions along the way. On the other hand, these writers are not willing to deprive general principles of their usual role in arguments for relatively specific maxims and judgments. General principles and factual premises do entail specific moral judgments, they admit, but the most suitable general principles, they insist, are those that summarize and are supported by the specific moral judgments in which we have the most confidence. We justify specific moral judgments, on their view, by deriving them from general principles, and the latter are supported in turn by a demonstration that the right moral judgments (other moral judgments) follow from them. This may be circular, but it is unavoidably and non-viciously so.

$\cdots$ If there is no common ground of moral conviction whatever between two individuals [who are in disagreement over a moral question], either at the level of general principle or the level of singular judgment, then the game is over before it begins. Logic cannot build castles on air. It is always a reasonable assumption, however, that two individuals in ethical disagreement over one question can find other matters on which they are in solid agreement. In order for one individual to "prove" that the other is wrong in a given belief he must use those beliefs and principles of the other party which he himself shares. He must show the other party that the belief he is currently defending is inconsistent with one of his own principles, or if the subject of dispute is one of the other party's principles, that it would commit him to a specific judgment which he would be embarrassed to make. The way to convince another party of the truth of a general moral principle is to show him that it summarizes and renders coherent his own actual convictions better than any alternative principle.

Feinberg, Justice, Fairness and Rationality, 81 YALE L.J. 1004, 1019-20 (1972). 
conclude that the judiciary now should frankly take up the theory and wield it in support of (or, as the case may be, opposition to) various welfare-rights claims? We have already seen that the theory itselfs suggests reasons for caution in approaching this question. ${ }^{\mathbf{1 2 7}}$

Imagine a claim to state provision of "decent" housing, brought on behalf of a family including children of educable age, that plainly has no other presently available way to acquire such housing, and appealing to constitutional texts that are at best inconclusive on the matter-say those guaranteeing equal protection of the laws, or protecting life, liberty, and property against deprivation attributable to the state, or obligating the state to furnish education. ${ }^{128}$ Let us further suppose that the judges are intuitively drawn to recognition of the claim. Their considered judgments tend to confirm it. They are, moreover, conversant with a body of speculative moral theory supporting the claim, which they find persuasively justified by the kind of coherence already described. And all are further agreed that the question cannot be conclusively resolved by historical research into what the framers had in mind when they drafted and adopted the cited constitutional texts. ${ }^{120}$

Nevertheless, we may expect to find the judiciary reluctant to determine whether the claimed right to adequate housing exists and is to be enforced if necessary by judicial mandate. The court's explanation of its abstinence is likely to suggest not so much denial of the claimed right as judicial incompetence to answer the question, or inability to answer it without violating a felt obligation to lay aside personal "philosophy" or moral convictions in dealing with legal claims. There is a rich and distinguished judicial and scholarly literature exploring possible reasons for self-restraint of this sort. ${ }^{130}$ To see how the suggested "Rawlsian" account of judicial review relates to this literature, some crude restatement of some of the literature's insights is in order.

It is not immediately clear what features of our hypothetical case should excite special doubts on the judges' part about their competence, in the most direct sense of personal ability to perform the intellectual operations, or to get at the information required to determine the exis-

127 See text accompanying notes 85-105 supra. to all.

128 E.g., N.J. CoNsT. art. 8, § 4, guaranteeing a "thorough and efficient" education

129 Perhaps not many would argue seriously against Professor Karst's statement that, as a matter of actual history, "[t]oday the fourteenth amendment embodies much of what has become our natural-law Constitution." Karst, Not One Law at Rome and Another at Athens: The Fourteenth Amendment in Nationwide Application, 1972 WasH. U.L.Q. 383. See Frank \& Munro, The Original Understanding of "Equal Protection of the Laws," 1972 WASH. U.L.Q. 421, 476; cf. A. BICKEx, supra note 94, at 108-10.

130 E.g., Professor Bickel's eloquent study cited in the preceding note. 
tence or violation of the claimed right. The issue's resolution is likely to depend on a number of factors that are as accessible to judges as to legislators, most if not all of which are of a sort that in other contexts has often been regarded as well within-if not peculiarly within-the judicial province: a parsing of constitutional texts, tradition, or accepted principles of justice; or a correct reading of prevailing social standards and sentiments. Even the perplexing questions of economic feasibility which may be relevant-for example, whether there is some way to fulfill the claimed housing right without leaving the bottom worse off, on the whole, than it now is-do not seem different in essence from other issues that courts have deemed judicially triable, such as the economic issues in a major industrial nuisance litigation.

More plausible is the notion of remedial incompetence-the notion that judicial officers have no way of actually enforcing a determination in favor of a right to adequate housing, because fulfilling it entails actions (e.g.; raising and appropriating public funds and creating new administrative structures) that are immediately controlled by the executive and legislative branches, and involves a complex of subsidiary but vitally important choices which the judiciary lacks all basis for making. But this notion by itself fails to distinguish our welfare-rights case clearly from cases involving school desegregation ${ }^{131}$ and finance, ${ }^{132}$ and legislative reapportionment. ${ }^{133}$ In such cases courts have been willing to try remedial devices designed to harness to the court's announced principle the competence and accountability of nonjudicial public officials-most typically, a judicial mandate to legislative, executive, or administrative officers to prepare, submit, and carry out a corrective plan. Indeed the prognosis for one or another of these approaches would seem good, assuming a modicum of willingness to comply on the part of these nonjudicial officials. The notion of remedial incompetence seems to be at bottom a concern that the disposition to comply in our welfare-rights case will be less than in the reapportionment, segregation, and school-finance cases-and less than in the generality of cases in which governmental bodies are subjected to specific and declaratory remedies, not to mention simple awards of money damages. If this concern over compliance does not quite con-

131 E.g., Bradley v. Milliken, 468 F.2d 902 (6th Cir.), cert. denied, 409 U.S. 844 (1972). But see Bradley v. School Board, 462 F.2d 1058 (4th Cir. 1972).

132 E.g., Van Dusartz v. Hatfield, 334 F. Supp. 870 (D. Minn. 1971); Serrano v. Priest, 5 Cal. 3d 584, 487 P.2d 1241, 96 Cal. Rptr. 601 (1971); cf. Robinson v. Cahill, 62 N.J. 473, 303 A.2d 273, additional opinion, 63 N.J. 196, 306 A.2d 65 (1973). The decision of the Supreme Court in San Antonio Independent School Dist. v. Rodriguez, 411 U.S. 1 (1973), while reaching a conclusion on the merits contrary to those in Serrano and Van Dusartz, did not purport to base that conclusion on any notion of remedial incompetence. 133 E.g., Reynolds v. Sims, 377 U.S. 533 (1964). 
tradict our supposition (and the predictable protestations of the judges $)^{134}$ that they find the shelter claim intuitively appealing, it can be only because the judges at the same time doubt their ability to make it seem so clearly appealing to others. But why would judges who themselves are convinced by the moral philosopher's arguments be unable to persuade others in turn?

A more powerful and sophisticated version of the remedial incompetence notion would emphasize the amoebalike quality of budgetary and redistributive politics. If judicially forced to respond to this claim on behalf of the poor, the political dynamic might reestablish its equilibrium by forsaking some other existing program oriented towards their needs. ${ }^{\mathbf{1 3 5}}$ But if the underlying moral theory suggests a broad spectrum of judicial protection against such possibilities, ${ }^{136}$ then everything once again seems to turn on how confident the judges are that the theory can be wielded persuasively enough to induce compliance on all relevant fronts.

So we reach another interpretation of the incompetence notion: that the court lacks modes of articulation and explanation under which it can decide the case and maintain its appearance of answering to external principle, the moral source of its influence on other parts of government. Recognition of the claimed right to adequate housing or of its violation might depend on factors which, although no less appraisable by judges than by legislators, or by adjudicatory than by legislative process, might nevertheless seem too vague, too ineffable, or too debatable to furnish an acceptable basis for judicial action. A judicial judgment on the matter might seem dictatorial, whereas a parallel legislative judgment never could, given its representative inputs and likely adverse impact on the narrow self-interest of the majority.

We have been assuming throughout this discussion that the shelter claim is intuitively appealing to the judges, and perceived by them as coherent with a speculative theory which itself coheres with a much broader range of evident societal ideals and practices. In light of this assumption, every reason we have been able to give for judicial abstinence seems at first glance troublesome. We seem to be saying that a decision which, once truly understood, would not popularly and genuinely be felt to be repugnant on its merits, may nevertheless be unacceptable because it is destined not be understood. 
How does this concern for the understandability of judicial decisions fit with our suggestion for a Rawlsian account of the institution of judicial review? ${ }^{137}$ In that account, judicial review seemed to presuppose the following:

1. Given the society's evolutionary circumstances, there is a likelihood that even a representative, majoritarian legislature will sometimes act (or fail to act) in ways which violate principles of justice.

2. On a significant number of occasions, these violations will be such that they can be convincingly enough demonstrated by judges to induce willing rectification, although they are not so immediately visible and repugnant as to prevent them from occurring in the first place.

3. When violations are judicially demonstrated-or when they are determined within a course of judicial interventions which on the whole succeeds in demonstrating the violations which it determines-the political branches will comply with corrective judicial mandates.

Given Rawlsian premises, acceptance of judicial review thus reflects a belief that it is possible and useful to cultivate a special capacity for evaluating the compliance of legislative action (inaction) with principles of justice or their derived constitutional embodiments, and for persuading the generality of citizens to recognize discrepancies when they occur.

Now our discussion of judicial abstinence from welfare-rights claims has supposed that judges may approve a claim as in accordance with moral theory coherently expressing popular morality, and yet be incapable of performing the overt intellectual movements required for valid judicial review (sometimes called "reasoned elaboration" of, or "reasoned argument" from, accepted premises). If one believes, as we have just posited, that courts are sometimes capable of recognizing discrepancies and convincing the public of their existence, it is unclear how a court which privately acknowledged the coherence of a claimed right with public morality would be incapable of demonstrating that coherence through reasoned argument-unless "reasoned argument," perhaps surprisingly, means something different from effective persuasion. The question we must face, then, is why we tend to restrict the allowable mode of judicial persuasion to "reasoned argument" in some narrow sense of simple chains of reasoning from 
initially established premises or data. Why do we not embrace other potentially effective modes of persuasive discourse, such as the patient, roundabout, indeed circular, style of justification by coherence, of which Rawls is such a notable exemplar?

The answer, not so mysteriously after all, lies in the intellectual complexity that seems bound to attend efforts to justify moral theories, and to derive specific rights from them by coherence-style argument. The difficulty is perhaps adequately suggested by the first two parts of this essay. We did not there undertake to review the many interconnecting strands of the fabric of arguments justifying the theory of justice as fairness. Yet we did catch a glimpse of the kind of intellectual effort demanded of one who would draw welfare rights out of a theory so formulated that it can plausibly claim justification through the coherence it lends to the considered moral judgments of contemporary representative social critics. Even assuming that the coherence-justification of the theory, and the derivation of welfare rights from the theory, could in principle be made ultimately compelling to the generality of citizens, the possibility remains that the intellectual journey is too difficult and tortured to fit the Rawlsian account of judicial review. The intrinsic values ascribed by justice as fairness to equal participatory rights, and their connection with the preeminent social good of selfrespect, ${ }^{138}$ seem to indicate that Rawls contemplates fairly strict limits on the intellectual capacities and exertions that may be demanded of citizens as the condition of their being satisfied that controversial judicial mandates are indeed correct-limits perhaps strict enough to rule out judicial vindication of certain substantive rights which, Rawls also teaches, would be honored in a good society.

Here, then, is the nub: certain societies may have reached a stage of development in which shared or overlapping senses of justice are implicit or emergent among the generality of citizens, but not fully and explicitly acknowledged by most of them except, perhaps, in their rarest moments of maximum lucidity and detachment. Such societies are potentially but not actually in a well-ordered condition in which their affairs are effectively regulated by shared principles of justice. It seems that societies lying within this evolutionary range have the clearest uses for judicial review that appeals directly to principles of justice. But it also seems that the further such a society is from the actuality of a well-ordered condition-the more primitively developed is its common sense of justice - the greater will be both that society's need for such judicial review and the difficulty its judges will have in holding 
to a tolerable level the associated costs in participatory inequality which damages self-respect.

Thus it seems to be the terms of the trade-off between justice in participatory rights and justice in substantive rights that would account, in a Rawlsian view, for the position that rights can be recognized only through judicial reasoning which proceeds simply from previously established premises, or, in cases in which such reasoning proves fruitless, through a new expression of political consensus (through formalities of amending the constitution). On this interpretation, contemporary differences of view regarding the question of judicial "activism," and secular swings of general opinion on that question, could be said to reflect differences or shifts in the relative weights accorded participatory equality and substantive rights, or differences in perceptions about where our society stands along the range of potentially (but not actually) well-ordered ones.

\section{B. Moral Theory as a Backdrop for Positive Entitlements: The Question of Judicial Activism}

Now judgments made within the foregoing frame of thought may tell us that courts should not cut welfare rights out of the whole cloth of speculative moral theory-not Rawls' theory, at any rate-and foist them on resistant legislatures. But such judgments do not exhaust the question of whether judges should ever allow such a moral theory to become a guiding influence, or an acknowledged one, in adjudication. There remain to be considered the inescapable judicial functions of construing constitutional and statutory materials whose significance for a given dispute is debatable, and of determining the correct application to such materials of due process and equal protection guaranties in their formal and non-substantive aspects. Perhaps a theory like Rawls' can impart meaning and direction to judicial events occurring in the wake of constitutional or legislative initiatives that arise, so far as the theory is concerned, quite spontaneously.

For one thing, the theory may help us see that constitutional or statutory establishment of insurance rights ${ }^{139}$ may be understood as fulfilling claims of justice and right. Insurance rights might otherwise be viewed as mere responses to external economies of consumptionthat is, provision of goods and opportunities might be justified solely by a perception that one person's enjoyment of those goods and opportuni-

139 The only such rights commonly encountered in extant American constitutions pertain to education. For an example of a constitutionally protected right to education, see note 128 supra. 
ties has consequences that are beneficial for others. ${ }^{140}$ The externaleconomies explanation seems particularly well-suited for a scheme of public provision of certain goods that uses a plan of general provision rather than a needs test, ${ }^{141}$ inasmuch as (1) any claims of justice and rights might seem more naturally met by general monetary transfers, ${ }^{142}$ and (2) the plan provides for persons who would not suffer involuntary deprivation in its absence-a gratuity most obviously explainable as a libertarian ${ }^{143}$ response to a perception that without public subsidy each individual would allocate less private income to the good in question than would be socially optimal.

Our suggested account of constitutional welfare rights may help us resist the external-economies explanation. It offers reasons why social-minimum claims (i.e., claims of justice and right) might give rise to constitutionally protected insurance rights. ${ }^{144}$ It further helps us see that legislation creating such rights may be regarded as justice-inspired supplementation of the constitutional catalogue (if there is any) of surrogates for the social minimum-as legislative recognition of items omitted from the constitution, perhaps because the then-prevailing evolutionary circumstances did not urgently suggest them (e.g., the country was not so wealthy then, or so oriented to technology and educational credentials, or so committed to litigation as a way of resolving

140 The benefit may consist of allaying external diseconomies, and those diseconomies might be moral as well as material. The members of society might be humanitarians, made uncomfortable by awareness that other persons are experiencing certain kinds of deprivations. See Musgrave, The Role of Social Insurance in an Overall Program for Social Welfare, in The Princeton Syarposiom on the American System of Social Insurance 23, 25 (W. Bowen ed. 1968). A speculative theory of justice might help us account for these feelings. Insofar as it does, a purpose of dealing with "moral" external economies of consumption will tend to merge with a purpose of doing justice.

141 Under a "needs test" plan, public provision for the specified want is made only insofar as the person in want cannot afford to satisfy it out of private income. Under a "general provision" plan, provision is made for whoever has occasion to accept it, regardless of his private income. Public housing and public education, as commonly administered at present, illustrate the two plans respectively.

142 General monetary transfers are more respectful of the liberty of the recipient, allowing him to define his own needs. With regard to certain, rather narrowly limited, goods and circumstances, the notion of "paternalism" may provide an alternative rationale for the transformation of social-minimum claims into insurance rights. As Rawls puts it, this notion reflects the fact that persons in the original position

will want to insure themselves against the possibility that their powers are undeveloped and they cannot rationally advance their interests, as in the case of children; or that through some misfortune or accident they are unable to make decisions for their good, as in the case of those seriously injured or mentally disturbed.

... [P]aternalistic intervention must be justified by the evident failure or absence of reason and will ... and [paternalistic principles] must not be interpreted to license assaults on one's convictions and character by any means so long as these offer the prospect of securing consent later on.

RAwLS 248-50.

148 "Libertarian" because the method chosen is to subsidize, not compel, additional consumption.

144 See text accompanying notes 121-23 supra. 
a wide range of controversies). Should the legislature become convinced that good $G$, in addition to any others mentioned in the constitution, must be covered by a just social minimum whose other components and upper limits remain unspecifiable, a new insurance right seems an appropriate response, with or without a needs test. ${ }^{145}$ Moreover, the account suggests a special reason why such justice-inspired welfare rights might be guaranteed to everyone regardless of need. This approach may contribute to the workability of the legislative system by relieving it from the baffling task of precisely identifying and costing all items in the catalogue of surrogates before providing for those which it has been able to identify. ${ }^{140}$

Now one may fairly ask why it is at all important whether a constitutional guaranty or legislative program is to be taken as impelled exclusively by considerations of efficiency and external economies, or rather (at least in part) by considerations of justice and rights. Are these inferential understandings likely to have any effect on legislative and judicial behavior? A legislature's failure to implement a constitutional guaranty understood to be for the benefit of the general public which it directly represents is more easily excused-or at least over-

145 One possible objection to dispensing with a needs test and using a generalprovision plan (when the program's purpose supposedly is to satisfy claims of justice and right rather than realize external economies of consumption) might be that a general-provision plan, by shielding all beneficiaries of the publicly financed operation from having to pay specifically for benefits received (through fees, user charges, or special assessments), unnecessarily impairs the combined effectiveness of the pricing and voting processes in reaching an efficient allocation of resources through the public fisc. See $\mathrm{R}$. Musgrave, The Theory of Public Finance 116-35 (1959); and compare Rawls' discussion of the "exchange branch" at RAwLS 282-84. Put a little differently, the thought would be that, as to all persons who can easily afford to pay full costs out of private income, provision of a particular good or service "free"-i.e., financing its cost out of general revenues-can only be justified by, and so must imply, a judgment that the good or service is best regarded as a "public good," for example because consumption of it radiates indivisible external economies. But this seems hypertechnical. Consistent with a view of the good or service in question as a welfare right would be a supposition that just about everyone who can afford to pay for it out of private income would choose to do so were it not publicly provided. $C f$. Michelman, supra note 17 , at 30. Moreover, as previously discussed in the text, the cost of the entire welfare-rights package is likely to be smaller than the appropriate minimum guaranteed income level. Therefore, any provision out of general revenues of specified goods and services can be taken into account, and distributionally neutralized, in public deliberations over, say, the proper rate configuration (including negative rates) of the income tax.

146 Under the needs-test approach, a person is guaranteed a good or service insofar as he needs it and cannot afford it. We have to consider, though, what is meant by the statement that a person "cannot afford" something. What we usually mean, I think, is that even if he had the means immediately available to pay for what he needs, the result would be to force his consumption of some other good or service below some stated or assumed level. In terms of the present discussion, we could say that a person cannot "afford" the cost of satisfying a given need if paying it would disable him from satisfying other needs in the welfare-rights catalogue of surrogates for the just social minimum. Thus a needs-test approach entails the baffling task mentioned in the text. A general-provision approach may alleviate the problem, but will not entirely avoid it. The legislature will still need to consider whether provision for the want in question is likely to have economic ramifications that will rule out provision for other wants on the emergent list, leaving the bottom's total situation without clear improvement. 
looked-than its failure to accord persons their rightful claims against that represented public. Thus a convincing claim of justice-inspired right may lend a special force to legislative advocacy. And it may undergird judicial boldness and inventiveness in exploiting openings and opportunities spontaneously provided by the legislature: although a constitutional guaranty of, say, a "thorough and efficient education" may not be deemed one which the court can enforce from scratchwhether because it entails the appropriation of funds and design of administrative structures, or because the standards of thoroughness and efficiency are not justiciable ${ }^{147}$ - the court may yet find ways of building on legislative foundations, ways not necessarily contemplated or welcomed by the legislature. And the same may be true where the welfare right which the legislature has spontaneously begun to honor cannot be connected with any specific constitutional text.

The last point deserves some expansion. It suggests further study of the interplay between the legislative/administrative and judicial branches in the process of revealing and realizing welfare rights. Can it be said that there are some claims which, originating in legislative actions which could not have been judicially compelled, are thereupon accorded unusually assertive judicial support? ${ }^{148}$ And that the principles on which these claims are picked out bear logically expressible relationships to principles of justice or rights generated by intellectually coherent philosophical theories? If so, a legislature which might lawfully have remained quiescent would find, once having adopted a limited and qualified program for meeting needs favored by such theories, that the limitations and qualifications would be placed under severe strain by the judiciary. At the extreme, the courts might prevent repeal of the program. ${ }^{149}$ Less drastically, the courts might invalidate

147 But see Robinson v. Cahill, 118 N.J. Super. 223, 287 A.2d 187, supplemented, 119 N.J. Super. 40, 289 A.2d 569 (1972), modified, 62 N.J. 473, 303 A.2d 273, additional opinion, 63 N.J. 196, 306 A.2d 65 (1973) (state system in which districts operated on varying per-pupil expenditures, and some districts were markedly ill-equipped and ineffective, held unconstitutional under "thorough and efficient" requirement).

148 Consider the notion of "fundamental interests" capable of triggering "strict review" in the two-tiered equal protection paradigm of recent glory. See, e.g., Michelman, supra note 17 , at $22-23$.

The utility and future prospects of the two-tier approach have recently been questioned by Gunther, The Supreme Court, 1971 Term-Foreword: In Search of Evolving Doctrine on a Changing Court: A Model for a Newer Equal Protection, 86 HARv. L. REv. 1, 8-20 (1972). But see the Supreme Court's even more recent confirmation of the method in San Antonio Independent School Dist. v. Rodriguez, 411 U.S. 1 (1973).

149 Consider Reitman v. Mulkey, 387 U.S. 369 (1967), one of the famously problematic decisions of recent years. Does it not suggest an affirmative duty on the state's part to enact an antidiscrimination law-a duty whose initial performance the Court could not compel because it had no way of settling questions involving the proper locus of enforcement responsibility, administrative procedure, nature and gravity of sanctions, marginal applications, and so forth? The enacted statute reflected the Iegislature's preferences-or at least one-time preferences-concerning these matters. 


\section{statutory eligibility conditions; ${ }^{150}$ strictly construe delegations of} authority to administrative officers to fashion such conditions; ${ }^{\mathbf{1 5 1}} \mathrm{im}$ pose exacting standards of procedural nicety in processing admission to and exclusion from assistance ${ }^{\mathbf{1 5 2}}$ invalidate seemingly plausible classifications among potential eligibles; ${ }^{153}$ or create seemingly inflexible requirements of equal expenditure for all program beneficiaries, perhaps as a device for ensuring that at least the minimum acceptable level of service will be attained for all. ${ }^{154}$ The whole process may be interpreted as the judiciary's seizing upon a legislative initiative which it could not, within separation-of-powers constraints, have compelled in spite of felt claims of right, for the purpose of thenceforth securing and expanding the fulfillment of such claims. Viewed from a more global and detached perspective, the process may be regarded as one of mutually reinforcing interaction between the two branches, built into the constitution by the framers in the interest of justice.

Outright repeal (or, in this case, constitutional-amendment override) reflects no dissatisfaction with these adjective or finely balanced features of the law, but rather a broadly unconstitutional purpose (as we are now supposing) of withdrawing protection owed. In blocking repeal, the Court did not have to take on the uneasy task of reviewing legislative detail work and fine tuning (as would have been necessary under a decree purporting to require initial enactment) or jeopardize its authority by inviting an intransigent legislature to answer a decree with inaction. (Even a subsequent legislative refusal to appropriate funds to pay for enforcement could not prevent effectuation of the Court's will through private civil litigation.) See generally Karst \& Horowitz, Reitman v. Mulkey: A Telophase of Substantive Equal Protection, $1967 \mathrm{~S}$. C $\mathrm{T}$. REv. 39.

150 See Smith v. King, 277 F. Supp. 31 (M.D. Ala. 1967) (Alabama's "substitute father" ("man-in-the-house") rule, as applied to federally-assisted AFDC programs, denies equal protection), aff'd, 392 U.S. 309 (1968) (Alabama rule is invalid on grounds of conflict with federal statute); $i d$. at 334 (Douglas, J., concurring) (Alabama rule denies equal protection); cf. Potts v. Breen, 167 III. 67,47 N.E. 81 (1897) (state board of health not authorized by statute to require vaccination as condition of school attendance; query whether statutory authorization would be valid in light of state constitution's guaranty of "a good common school education").

151 See Alexander v. Thompson, 313 F. Supp. 1389 (C.D. Cal. 1970) (state statute empowering local school board to "prescribe rules ... for the government and discipline of the schools" would be unconstitutional delegation if construed to authorize grooming regulations leading to exclusion from school); Potts v. Breen, 167 IIl. 67, 47 N.E. 81 (1897).

152 See Goldberg v. Kelly, 397 U.S. 254 (1970) (due-process hearing required prior to terminating welfare payments on grounds of recipient's noneligibility); Holmes v. New York City Housing Auth., 398 F.2d 262 (2d Cir. 1968) (N.Y.C. Housing Authority, receiving 90,000 applications and admitting 10,000 families annually, may violate due process by not processing applications chronologically or in accordance with published standards, or by lot, "or in any other reasonable and systematic manner," by not notifying applicants of their status and by not disclosing reasons for rejecting applications).

153 See Thomas v. Housing Auth., 282 F. Supp. 575 (E.D. Ark. 1967) (defendant's regulation excluding unwed mothers not authorized by statutory delegation of power to make needful regulations consistent with public housing statutes, even though purpose was to avoid objectionable behavior in project; regulation is rigid and overbroad and "does not square with the humane purpose of the low rent housing program," id. at 581) ; cf. Shapiro v. Thompson, 394 U.S. 618 (1969) (requirement of a year's residence in state, as condition of eligibility for public assistance, unconstitutionally burdens right of interstate travel). But see Dandridge v. Williams, 397 U.S. 471 (1970), rev'g 297 F. Supp. 450 (D. Md. 1969).

154 See Serrano v. Priest, 5 Cal. 3d 584, 487 P.2d 1241, 96 Cal. Rptr. 601 (1971). Contra, San Antonio Independent School Dist. v. Rodriguez, 411 U.S. 1 (1973). 
This interpretation supposes (adopting once again for a moment the judiciary's perspective rather than the more global one) that the same legislature which could not be compelled in the first place to inaugurate a welfare-rights program can nevertheless be led by judicial pressure and authority to deepen and expand such a program once adopted, without prohibitive risk that the obvious alternative of legislative withdrawal will occur. A part of the hypothesis, then, is that courts make judgments (call them tactical judgments, if you like) about these likelihoods; and that these judgments will prove to reflect accurate judicial intuitions or perceptions of the degree to which the legislative initiative can be seen as responding to claims of natural rights-that is, as consisting with an emergent public sense of justice expressible by principles in a coherent theory of justice. If the hypothesis to this extent seems appealing, then further steps may be suggested: that as judges go about their business of selectively translating constitutional and statutory offerings into welfare rights - as they play their role in the authorship of positive entitlements-they should conscientiously try to clarify in their own minds some systematic moral theory which justifies and accounts for their decisions, should not shrink from incorporating such thought in their public explanations of what they do, and should be prepared at an appropriate stage in the emergence of a welfare right to declare that such a right exists. Such judicial behavior at any rate would seem to accord with our suggested Rawlsian account of welfare rights and judicial review under nonideal conditions. ${ }^{155}$

\section{Moral Theory and Neutral Principles}

All of this may have some bearing on the problem of neutrality of principle in constitutional adjudication. ${ }^{156}$ One tries to understand various legal claims and entitlements in a certain way-that is, as reflecting "natural rights" which in turn are suggested by principles of justice in a coherent theory of justice. Then neither rights nor principles can stand in isolation from any other rights or principles contained in or suggested by the same theory. A right is valid only for cases to which it properly applies under the theory which supports it; every right is bounded by other rights, every principle must connect with other principles. A right too far distended is injustice. As Professor Deutsch, following Ernest Brown, correctly insists, there can be no ultimate,

150 For discussion of neutrality in constitutional adjudication, see A. Brckex, supra note 94, at 49-65; H. WeCESLER, Toward Neutral Principles of Constitutional Law, in Principles, Politics, and Fundanrental Law 3 (1961); Deutsch, Neutrality, Legitimacy, and the Supreme Cont: Some Intersections Between Law and Political Science, 20 STAN. L. REv. 169, 178-97 (1968). 
total "neutrality" in the application of principles to cases, unless the principles used all belong to one family of revealed principles whose members are exhaustively interlaced across the whole universe-or at least a sizeable and somewhat self-contained region-of social problems. ${ }^{157}$

Suppose a statutory public-housing program is administered in a way that promotes or supports a demeaning, stigmatizing kind of racial segregation; and that judicial proscription of that method of administration seems most likely to result not in correction but in termination of the program. Constitutional texts provide no unambiguous guidance, and the problem at first glance seems to have no obviously satisfactory solution. ${ }^{158}$ A judge imbued with Rawls' theory does at least have recourse to a principled way of organizing and directing the search for an answer. The judge may consider that the housing program is reflective of moral entitlements, and may further consider that the existing method of administration seems severely damaging to the goal of advancing self-respect deemed centrally important in the same moral theory that suggests the moral-entitlement interpretation of the housing program. Thus the case seems to pit a welfare-rights principle against a self-respect principle. The virtue of the moral theory, insofar as it is found persuasive, lies in its suggestion that welfare rights ideally work in the service of self-respect. ${ }^{159}$ There may be reason to believe, in the existing non-ideal situation in which the principles are in immediate conflict, that short-term subordination of self-respect to welfare will yield a long-term strengthening of self-respect. If not, the welfare program must lose out - that is, the court must insist on its being administered in a way that predictably will lead to its demise. Whatever the conclusion, it will seem more bearable if the court can give a neutral explanation for it-one which both has some persuasive force and will not be embarrassing in future cases. A comprehensive, coherent theory of social justice, such as Rawls has attempted, holds out the hope that such explanations can be given. The theory, as Rawls would have it, serves as

a guiding framework designed to focus our moral sensibilities and to put before our intuitive capacities more limited and manageable questions for judgment. ... If the scheme as a whole seems on reflection to clarify and order our thoughts, and if it tends to reduce disagreements and to bring divergent

157 Deutsch, supra note 156, at 187-90; Brown, Book Review, 62 CorUM. L. REv. 386 (1962).

158 See, e.g., Note, Public Housing and Urban Policy: Gautreaux v. Chicago Housing Authority, 79 YAIE L.J. 712 (1970).

159 See text accompanying notes $62-71,77-80$ supra. 
convictions more in line, then it has done all that one may reasonably ask. ${ }^{160}$

Professor Deutsch seems satisfied that there can be no comprehensive moral theory capable of imbuing judicial handiwork, extended over time and subject matter, with such neutrality as we have been considering. He may be right; but it is important to see just what his denial means. A work like Rawls' suggests that such a theory is not a logical or verbal impossibility. More study is needed, but it would not amaze me if Rawls' theory does turn out to be worthily comprehensive and coherent-that it does offer reasons, both general and somewhat persuasive, that help organize the search for answers across a broad spectrum of testing cases.

If so, then Professor Deutsch's denial must refer not to natural limitations on the achievable scope, refinement, or internal coherence of possible theories of social justice, but to the illegitimacy of transforming any such theory into law-of certifying it for deployment by judges. That, of course, is no trivial problem. But its ultimate signifcance must be judged in light of three interrelated features of Rawls' theory. First, the theory, while coherent and comprehensive, is at the same time "loose." It consists of broad principles which derive their meaning not from verbal precision but from the rich cumulation of persuasions-some scientific, some traditional, some intuitive-in which they are embedded. There is no possibility that the theory could be applied in any automatic way, or be transformed into a code susceptible of automatic application. Second, popular decision processes are strongly valued by the theory. ${ }^{101}$ There is no possibility that judges imbued with it could ever lose sight of the "counter-majoritarian difficulty."162 Third, the theory seeks ultimate justification by its claimed coherence with the latent morality of the people. And this gets us back to Professor Deutsch who, despairing of ultimate neutrality through an exhaustive and coherent system of principles of justice, suggests instead that a principle is applied neutrally if it is applied harmoniously with popular will and understanding. ${ }^{163}$ Rawls' effort suggests the possibility that Deutsch's two interpretations of neutrality - the totally objective view which he finds impossible and the qualified, public-acceptance view which he espouses-may in the end be made convergent.

The vehicle of convergence would be something akin to the reflective equilibration which lies at the core of Rawlsian moral argu-

160 RaWLS 53.

101 See text accompanying notes 101-05 supra.

162 A. Bicker, supra note 94, at 16-23.

${ }^{163}$ See Deutsch, supra note 156, at 192-97. 
ment. "Reflective equilibrium" perhaps offers a paradigm of judicial review:

In describing our sense of justice an allowance must be made for the likelihood that considered judgments are no doubt subject to certain irregularities and distortions despite the fact that they are rendered under favorable circumstances. When a person is presented with an intuitively appealing account of his sense of justice (one, say, which embodies various reasonable and natural presumptions), he may well revise his judgments to conform to its principles even though the theory does not fit his existing judgments exactly. He is especially likely to do this if he can find an explanation for the deviations which undermine his confidence in his original judgments and if the conception presented yields a judgment which he finds he can now accept. ... [T] he best account of a person's sense of justice is not the one which fits his judgments prior to his examining any conception of justice, but rather the one which matches his judgments in reflective equilibrium. ... [T] his state is one reached after a person has weighed various proposed conceptions and he has either revised his judgments to accord with one of them or held fast to his initial convictions (and the corresponding conception $)^{164}$ [or made mutual adjustments in both convictions and conceptions $].{ }^{165}$

Can we see the courts as arbiters in such a process at a public level? Could a theory like Rawls' serve as the initial matrix for this processas the provisional "conception" which is thenceforth dialectically to be brought into harmony with the network of "considered judgments" reflected in statutes, customary forms of social behavior, constitutional texts and historical traditions (including those concerned with the intent of the framers)? The answer to the latter question depends entirely on how successfully Rawls has been able to do what he set out to do.

To some this will seem (as it does to me at times) an utterly trivial thesis, without explanatory power or practical significance. Its triviality seems to turn on how fanciful one finds the notion (I have swings of mood about it) that there will someday appear some speculative moral theory which displays both sufficient incisiveness to contribute toward the solution of testing cases, and sufficiently persuasive and accessible coherence with latent popular morality to deserve judicial recognition. At the very least, the thesis may counsel skepticism 
toward any insistence that the legal and moral orders are, logically and intrinsically, worlds apart, separated if not by a void then by an ether through which (at most) only occasional and inarticulate influences can pass. It denies that adjudication is a process inherently incapable of handling the kind of stuff of which moral philosophy is made, much as our intuitive arithmetical imagination cannot handle numbers compounded of the square root of minus-one. It suggests that the difficulty we experience is not with the logical possibility of interlacing moral speculation and law, but with the state and condition of moral theory itself-a state characterized by complexity causing inaccessibility and irresolvable controversy. Who dares predict that this state can ever be transcended? Not I; at least not now. But I will confess that Professor Rawls persuades me to keep my mind open. 